\title{
STUDIES WITH INAGGLUTINABLE ERYTHROCYTE COUNTS. I. A METHOD FOR MEASUREMENT OF NET GAIN OR DEFICIT OF RED CELLS IN THE HUMAN SUBJECT
}

\author{
By ELMER L. DEGOWIN, RAYMOND F. SHEETS, AND HENRY E. HAMILTON \\ WITH THE TEChNICAL ASSISTANCE OF RUTH E. DAHLIN \\ (From the Department of Internal Medicine, State University of Iowa, University Hospitals, \\ Iowa City, Iowa)
}

(Submitted for publication May 19, 1949; accepted, February 17, 1950)

In 1919 Winifred Ashby (1) reported a method of studying the survival of transfused erythrocytes in the circulation of the recipient by means of differential agglutination. Blood of group $\mathrm{O}$ was transfused to patients of group A or B and measured specimens of the recipient's blood were mixed with appropriate anti-A or anti-B serum. After the recipient's cells were agglutinated, the inagglutinated cells were counted. The resulting values, minus a blank estimated on the recipient's cells, were considered as representative of the concentration of group $\mathrm{O}$ blood in the circulation. By this method the survival rate of transfused erythrocytes was studied for many days. In 1928 the method was extended by Landsteiner, Levine, and Janes (2) so that the survival of transfused cells of type $\mathrm{N}$ could be followed in the circulation of the type $\mathrm{M}$ recipient by counting the cells which were not agglutinated by anti-M serum.

The Ashby procedure has stood the test of 30 years as an experimental method. The objection raised by Isaacs (3) that the method does not distinguish between transfused cells and the young erythrocytes of the recipient has been amply refuted. Landsteiner, Levine, and Janes (2) transfused $\mathrm{M}$ blood to $\mathrm{N}$ recipients and agglutinated the donor's cells instead of those of the recipient and found the disappearance rate similar to that obtained by the opposite procedure. Reticulocytes have been shown to possess the same affinity for agglutination as older cells by Callender, Powell, and Witts (4) and Young, Platzer, and Rafferty (5). More recently McKerns and Denstedt (6) labeled the erythrocytes of one blood group in vitro with sulfhemoglobin and showed that agglutination separated the labeled cells from those of different group in a mixture in the test tube.

The method of differential agglutination has proved to be a valuable procedure in studying the life span of transfused erythrocytes $(1,4,7-10)$. It has been widely used in the evaluation of methods of storage of blood for transfusion (11-16). The Ashby technique has been employed in studying the mechanisms of hemolysis in many types of anemia, such as pernicious anemia (17-19), sickle cell anemia $(20,21)$, familial and acquired hemolytic anemia (22-24), nocturnal hemoglobinuria (25), hemolytic disease of the newborn (26, 27 ), and other disorders less well classified (28). The mechanisms of transfusion hemolysis have been elucidated by its use $(29,30)$.

The present paper is concerned with $A$. an evaluation of the accuracy of the method of counting inagglutinable cells, $B$. the demonstration of the effects of fluctuations in the plasma volume of the recipient, either peripherally or generally, on erythrocyte counts, and $C$. a method of measuring the net gain or deficit in the erythrocytes of the recipient by reference to transfused inagglutinable cells as biologic tags.

Antisera

Anti-A and anti-B sera were derived from blood of human donors of appropriate group. The natural agglutinins were increased in titer by injecting the donors intramuscularly with the A and B group-specific substances of Witebsky (31) (prepared by Sharp and Dohme Laboratories). Two or three weeks after injection, when the titer of isoagglutinins had attained a desirable value, blood was withdrawn, permitted to clot in the refrigerator, and the cells were separated from the serum aseptically. The titers observed in the test tube by the centrifuge technique frequently were between 1,000 and 2,000, as read macroscopically. The serum was inactivated at $56^{\circ} \mathrm{C}$. for one hour in a water bath to destroy complement and prevent the action of isohemolysins.

The volume of serum to be employed for an entire series of tests on one recipient was estimated and divided into small amounts sufficient for tests for a single day. All aliquots were then frozen and kept in that state un- 
til required for use. By this means stability of the antiserum for the experiment was increased.

Anti-M serum, prepared by the immunization of rabbits, was supplied in the dry state by the Lederle Laboratories, Inc. This was dissolved in isotonic saline solution just before use.

\section{Technique of total erythrocyte counts}

A freely bleeding puncture was made in the ear lobe of the subject after the skin had been washed with alcohol and dried. From a large drop of blood, samples were drawn into three Thoma erythrocyte pipettes. The blood columns were drawn to the mark 0.5 and the pipettes then filled to the mark 101 with Gower's solution. The pipettes were agitated in a Bryan-Garrey pipette rotor (manufactured by A. S. Aloe Co., St. Louis, Mo.) for 10 minutes and subsequently they were shaken by hand for about one minute. Both sides of a LevyHausser counting chamber with Improved Neubauer ruling were filled with the contents of one pipette, another hemacytometer was loaded from the second pipette. The third pipette was kept in reserve. After the cells had settled in the chambers the erythrocytes were counted in five squares, $0.25 \mathrm{~mm}$. on a side, on each side of the counting chamber. With a red cell count of $5,000,000$ cells per mm. ${ }^{3}$ the contents of 10 squares, or approximately 1,000 cells, were actually counted from one pipette. The counts obtained from the first and second pipettes were averaged. If the counts from the two pipettes differed by over 200,000 per $\mathrm{mm}^{3}$, the content of the third pipette was counted and the two closest counts averaged. All counting chambers, cover glasses, and pipettes were certified by the National Bureau of Standards.

\section{Technique of counting inagglutinable erythrocytes}

During most of the present study the method of Denstedt (32) was employed with minor modifications. In this procedure blood from a freely bleeding puncture of the ear lobe was drawn into a Thoma leukocyte pipette up to the mark 0.5 . The pipette was then filled to the mark 11 with $3.2 \%$ trisodium citrate solution $\left(\mathrm{Na}_{3} \mathrm{C}_{6} \mathrm{H}_{5} \mathrm{O}_{7}+2 \mathrm{H}_{2} \mathrm{O}\right)$. Another pipette was similarly filled. The contents of the two pipettes were expelled into separate clean dry serologic test tubes. A dry leukocyte pipette was filled to the mark 1.0 with the content from one tube and agglutinating serum drawn to the mark 11. The serum-cell mixture was expelled into a clean dry serologic tube. The duplicate mixture was treated likewise. The two tubes were centrifuged for one minute at 1,800 revolutions per minute. The tubes were then closed with rubber stoppers and shaken for 30 minutes, back and forth, in the long axis of the tubes, at 180 cycles per minute, through an arc about $3.5 \mathrm{~cm}$. long. The tubes were removed from the shaker and the contents permitted to settle for five seconds. The top layer of the supernatant fluid was then taken up with a capillary pipette and each side of a hemacytometer count- ing chamber was charged with the contents from a different tube. After the cells had settled the inagglutinated cells in all nine large squares, $1 \mathrm{~mm}$. on a side, were counted and the computation made as follows:

Inagglutinated cells per mm. ${ }^{3}$

$$
\left.=\text { (count in } 9 \mathrm{~mm}^{2}\right) \times \frac{10}{9} \times 22 \times 11 \text {. }
$$

In this procedure, when the inagglutinable cell count was 500,000 per mm. ${ }^{3}$, about 1,850 cells were actually counted from each of the two pipettes and the two counts were averaged. When the count was 250,000 , about 925 cells from each pipette were actually counted. All hemacytometer chambers, cover glasses, and Thoma pipettes were certified by the National Bureau of Standards.

Before transfusion the inagglutinable count of the recipient (the blank) was estimated for one or more days. Antiserum was not employed when it produced a blank which exceeded 50,000 per $\mathrm{mm}^{3}$ and most of the blanks were less than 20,000 .

\section{Transfusion procedure}

In most instances group $O$ blood was transfused to recipients belonging to group $\mathrm{A}$, in which case the inagglutinable cell counts were made with anti-A serum. In a few cases group $O$ blood was transfused to group B recipients and anti-B serum was used to make the inagglutinable cell counts. A few transfusions were made with $\mathrm{ON}$ blood to $\mathrm{OM}$ recipients and anti-M serum was employed to estimate the inagglutinable cell counts. As others have, we found that anti-N serum was unreliable in the estimation of inagglutinable cell counts.

All transfusions were made with fresh blood collected in an acid-citrate-dextrose solution in the proportion of $125 \mathrm{ml}$. of solution to $500 \mathrm{ml}$. of blood. In a few instances whole blood of group $\mathrm{O}$ was given to recipients of heterologous groups but a hemolytic reaction was produced in one case and in most transfusions the cells were separated from the plasma by centrifugation and washed three times in sterile $0.9 \%$ sodium chloride solution. The whole blood mixtures and cell suspensions were injected intravenously by gravity after filtration through a plasticized cloth filter (33). Most adult recipients were given $500 \mathrm{ml}$. of whole blood or the cells therefrom. In several small children larger proportionate doses were given. If they were able, the recipients were permitted to resume ordinary activity during the period of study.

The transfused whole blood or cell suspensions were carefully measured volumetrically and weighed. Samples of blood serum were taken several times during the first 24 hours after transfusion for estimations of serum bilirubin by the method of Malloy and Evelyn (34) and the serum hemoglobin by the procedure of Flink and Watson (35) slightly modified by us (36). Plasma volume estimations were frequently made before or during transfusion by injection of Evans blue dye, T-1824 (36). 


\section{ACCURACY OF THE ERYTHROCYTE COUNTS}

\section{Counting error}

The combined error of the blood diluting pipettes, of the spread of the cell suspensions in the counting chambers, and of the inaccuracies of cell counting was tested in one experiment. A citrated blood specimen was collected in a test tube and from this Thoma erythrocyte pipettes were filled to the mark 0.5, and then Gower's solution was drawn up to the mark 101. The pipettes were then agitated with the Bryan-Garrey rotor for 10 minutes. Both sides of the counting chamber were charged with the contents of one pipette, the cells were permitted to settle, and the counts were made by an enumeration of the cells in five squares, $0.25 \mathrm{~mm}$. on a side, in each side of the counting chamber. About 1,000 cells were actually counted. The test tube containing the blood specimen was inverted 20 times before filling each pipette. The counts from the two sides of the chamber were averaged. On one day 30 pipettefuls were counted. The test tube of blood was then placed in the refrigerator over night and 36 pipettefuls were counted the next day. All counts were performed by the same experienced technician. The counts on the two days showed no appreciable differences so that all 66 counts were evaluated together. The mean erythrocyte count was found to be 5.017 millions per $\mathrm{mm}^{2}$ The standard deviation was 49,200 , as computed from the equation

$$
\mathrm{SD}=\sqrt{\frac{\Sigma(\mathrm{x}-\overline{\mathrm{x}})^{2}}{\mathrm{~N}}} .
$$

Taking two standard deviations as a reasonable limit of error, the blood count was calculated to be $5,017,000 \pm$ 98,400 , an error of $\pm 1.9 \%$.

The experiment just cited does not take into account the error incurred in sampling a drop of blood from a skin puncture. To test this, together with the errors of pipettes, counting chambers, and enumeration, analyses were made of a large number of duplicate cell counts obtained by the same technician in routine observations in these studies. Three pipettes were filled from the same drop of blood from the puncture of an ear lobe. The data were unselected except that occasionally a value was discarded in favor of an additional count from the third pipette when the difference between counts of the pair exceeded 200,000 per mm. . $^{3}$ for the total cell counts. The data are given in Table I. In this the standard deviation of the means of pairs of counts in the same range has been calculated by the equation:

$$
\operatorname{SD}(\bar{A})=\frac{1}{2} \sqrt{\frac{\Sigma(\Delta A)^{2}}{n-1}},
$$

where $\bar{A}$ is the mean of two of a pair of counts, $A_{1}$ and $A_{2}$; $\Delta \mathrm{A}$ is the difference between $A_{1}$ and $A_{2}$; and $\Sigma(\Delta A)^{2}$ is the sum of the squares of the differences of the pairs of counts in the range under consideration. The number of samples is $n$.

The derivation of this equation assumes that the stand-
TABLE I

Error in counting total erythrocytes and inagglutinable cells as computed from differences between members of duplicate counts made from the same sample of blood from ear lobe punctures of

\begin{tabular}{|c|c|c|}
\hline $\begin{array}{l}\text { Range of cell counts } \\
\text { (Millions per mm. }\end{array}$ & $\begin{array}{l}\text { Number of } \\
\text { pairs of } \\
\text { counts }\end{array}$ & $\begin{array}{c}\text { Standard } \\
\text { deviation of } \\
\text { means of two } \\
\text { members of } \\
\text { pairs of counts } \\
(M \text { illions per } \\
\text { mm.s) }\end{array}$ \\
\hline $\begin{array}{c}\text { Total erythrocyte counts } \\
0 \text { to } 1.0 \\
1.0 \text { to } 2.0 \\
2.0 \text { to } 3.0 \\
3.0 \text { to } 4.0 \\
4.0 \text { to } 5.0 \\
5.0 \text { to } 6.0 \\
6.0 \text { plus }\end{array}$ & $\begin{array}{l}6^{*} \\
28 \\
65 \\
65 \\
65 \\
65 \\
29\end{array}$ & $\begin{array}{l}.041 \\
.042 \\
.045 \\
.051 \\
.050 \\
.051 \\
.053\end{array}$ \\
\hline $\begin{array}{c}\text { Inagglutinable cell counts } \\
0 \quad \text { to } .100 \\
.100 \text { to } .200 \\
.200 \text { to } .300 \\
.300 \text { to } .400 \\
.400 \text { to } .500 \\
.500 \text { to } .600 \\
.600 \text { to } .700 \\
.700 \text { to } .800 \\
.800 \text { to } .900 \\
.900 \text { to } 1.000 \\
1.000 \text { plus }\end{array}$ & $\begin{array}{l}65 \\
59 \\
65 \\
65 \\
65 \\
60 \\
49 \\
10^{*} \\
8^{*} \\
11^{*} \\
65\end{array}$ & $\begin{array}{l}.0010 \\
.0016 \\
.0022 \\
.0025 \\
.0029 \\
.0029 \\
.0039 \\
.0046 \\
.0055 \\
.0091 \\
.0093\end{array}$ \\
\hline
\end{tabular}
many individuals tion.

* Inadequate number of samples for accurate calcula-

ard errors of measurement of all counts in the same range are approximately equal. Therefore the standard deviations of all the differences in pairs of counts, $A_{11}$ and $A_{12}$, and $A_{11}$ and $A_{12}$, etc., are also equal. The difference between the members of a pair is $\Delta A_{1}=A_{11}-$ $A_{12}$. The mean value of

$$
\Delta A_{1}=\frac{1}{n} \sum_{i=1}^{n} \Delta A_{i}=0
$$

if there is no systematic error which makes the first reading higher or lower than the second of a pair. Then

$$
\operatorname{SD}\left(\Delta \mathrm{A}_{i}\right)=\sqrt{\frac{\sum_{i=1}^{n}\left(0-\Delta \mathrm{A}_{i}\right)^{2}}{n-1}}=\sqrt{\frac{\sum\left(\Delta \mathrm{A}_{i}\right)^{2}}{n-1}} .
$$

The mean value of duplicate counts is $\bar{A}=\frac{1}{2}\left(A_{i l}+A_{i 2}\right)$. Then

$$
\begin{aligned}
\operatorname{SD}\left(\bar{A}_{i}\right) & =\frac{1}{2} \sqrt{\operatorname{SD}^{2}\left(A_{i 1}\right)+\operatorname{SD}^{2}\left(A_{i 2}\right)}=\frac{1}{2} \sqrt{2 S^{2}\left(A_{i 1}\right)}, \\
\operatorname{SD}\left(\Delta A_{i}\right) & =\sqrt{S^{2}\left(A_{i 1}\right)+\operatorname{SD}^{2}\left(A_{i 2}\right)}=\sqrt{2 D^{2}\left(A_{i 1}\right)}, \\
\operatorname{SD}\left(\bar{A}_{i}\right) & =\frac{1}{2} \sqrt{\frac{\Sigma\left(\Delta A_{i}\right)^{2}}{n-1}} .
\end{aligned}
$$

With the data from duplicate counts the previously cited value of $5,017,000$ cells would have a standard deviation of 51,000 , or twice the standard error on either side of 
the mean would be $\pm 102,000$, as compared to $\pm 98,400$ in the test tube.

The analysis of the data for inagglutinable cell counts can only give an estimate of the sampling error, chamber spread, and enumeration. Errors attributable to the formation of agglutinates by the action of antiserum must be tested by experiments on blood mixtures in test tubes and are discussed under the heading of Serologic errors.

Berkson, Magath, and Hurn (37) devised the following equation to express the accuracy of red cell counts in the hemacytometer :

$$
V_{t}=\sqrt{\frac{(0.92 \times 100)^{2}}{n_{b}}+\frac{4.6^{2}}{n_{0}}+\frac{4.7^{2}}{n_{p}}}
$$

where $\mathrm{V}_{\mathrm{t}}=$ coefficient of variation in percentage; $\mathrm{n}_{\mathrm{b}}=$ total number of cells counted; $n_{c}=$ number of chamber specimens examined; and $n_{p}=$ number of separate pipette specimens employed. According to this equation a specimen containing 5,000,000 erythrocytes per $\mathrm{mm}^{.}$, counted by the technique which we employed for total cell counts, should have the following coefficient of variation:

$$
\mathrm{V}_{\mathrm{t}}=\sqrt{\frac{(0.92 \times 100)^{2}}{2000}+\frac{4.6^{2}}{4}+\frac{4.7^{2}}{2}}= \pm 4.53 \% \text {. }
$$

Taking the limits of error as twice the standard error on either side of the mean, this would be $5,000,000 \pm 9 \%$ or \pm 450,000 cells. Actually our data show that the red cell counts from skin punctures were made with approximately the accuracy of $5,000,000 \pm 102,000$ per $\mathrm{mm}^{.}$. We do not attempt to explain the greater accuracy of our counts except to state that the computations were made from unselected observations which were apparently unbiased. In no case was a discrepancy between two members of a pair of counts as great as 450,000 .

In a discussion of the technique of counting red blood cells Ponder (38) pointed out that the estimations of error by the method of Berkson and his coworkers represent the performance level in routine clinical laboratories and are by no means the lowest that can be expected by careful work. He states that the experienced investigator can attain an accuracy of slightly less than $\pm 3 \%$.

\section{Serologic errors in the inagglutinable cell counts}

Certain discrepancies in the inagglutinable cell counts obtained by the Denstedt technique, as performed in our laboratory, led to an extended study of the accuracy of the method. The antisera were tested by the inagglutinated cell counts which they produced with erythrocytes containing the specific agglutinogens (the "blank" counts). The various steps in the Denstedt procedure were investigated by using carefully measured mixtures of blood of heterologous groups in test tubes and comparing the observed inagglutinable cell counts with those expected by calculation. This led to a considerable modification in the technique and the evolution of a method more accurate in our hands.

Citrated specimens of blood or saline suspensions of erythrocytes belonging to group $\mathrm{A}$ or $\mathrm{B}$

TABLE II

\begin{tabular}{|c|c|c|c|c|c|c|}
\hline \multirow{2}{*}{ Serum } & \multirow{2}{*}{ Cells } & \multicolumn{5}{|c|}{ Serum dilutions } \\
\hline & & $1 / 1$ & $1 / 5$ & $1 / 10$ & $1 / 20$ & $1 / 100$ \\
\hline $\begin{array}{l}\text { Anti-A (m) } \\
\text { Anti-A (m) } \\
\text { Anti-A (m) } \\
\text { Anti-A (rr) } \\
\text { Anti-A (mm2) } \\
\text { Anti-A (mm2) } \\
\text { Anti-A (mm2) } \\
\text { Anti-B (ws) } \\
\text { Anti-B (ws) } \\
\text { Anti-B (ws) } \\
\text { Anti-B (ge) } \\
\text { Anti-B (ge) } \\
\text { Anti-B (ge) } \\
\text { Anti-B (ge) } \\
\text { Anti-B (ws2) } \\
\text { Anti-B (ws2) } \\
\text { Anti-B (ws2) } \\
\text { Anti-B (ws2) } \\
\text { Anti-B (ge) } \\
\text { Anti-B (ge) }\end{array}$ & $\begin{array}{l}\text { A (Dahl) } \\
\text { A (Dahl) } \\
\text { A (Sint) } \\
\text { A (Ham) } \\
\text { A (Dahl) } \\
\text { A (Dahl) } \\
\text { A (Dough) } \\
\text { B (Drake) } \\
\text { B (Lee) } \\
\text { B (Lee) } \\
\text { B (Lee) } \\
\text { B (Lee) } \\
\text { B (Drake) } \\
\text { B (Drake) } \\
\text { B (Hough) } \\
\text { B (Hough) } \\
\text { B (DeG) } \\
\text { B (DeG) } \\
\text { B (Hough) } \\
\text { B (Hough) }\end{array}$ & $\begin{array}{r}32,500 \\
26,000 \\
28,000 \\
405,000 \\
15,450 \\
3,100 \\
26,300 \\
3,049,500 \\
909,000 \\
3,795,000 \\
102,450 \\
253,500 \\
175,100 \\
\\
2,601,000 \\
3,085,000 \\
3,260,000\end{array}$ & $\begin{array}{r}1,350 \\
6,850 \\
48,500 \\
3,200 \\
2,150 \\
177,500 \\
171,360 \\
23,500 \\
41,150 \\
7,250 \\
7,100 \\
14,400 \\
19,900 \\
29,300 \\
91,150 \\
104,500 \\
99,500 \\
8,250 \\
9,400\end{array}$ & $\begin{array}{r}3,650 \\
2,950 \\
8,200 \\
48,500 \\
9,950 \\
2,700 \\
420,000 \\
85,350 \\
10,000 \\
18,800 \\
3,900 \\
2,250 \\
7,700 \\
9,200 \\
24,600 \\
24,600 \\
61,950 \\
42,050 \\
4,800 \\
5,050\end{array}$ & $\begin{array}{r}4,950 \\
15,500 \\
80,500 \\
37,800 \\
3,600 \\
\\
41,900 \\
17,500 \\
21,750 \\
6,700 \\
5,900 \\
12,900 \\
12,750 \\
991,400 \\
25,300 \\
122,000 \\
35,000 \\
6,850 \\
6,520\end{array}$ & $\begin{array}{r}85,500 \\
226,500 \\
428,000 \\
244,500 \\
\\
219,000 \\
281,500 \\
29,600\end{array}$ \\
\hline
\end{tabular}

Inagglutinable cell counts with various dilutions of antiserum, showing prozone phenomenon*

* Counts as cells per mm. ${ }^{3}$ 
TABLE III

Test tube titration of potency of anti-A serum (m) against $A$ cells, showing no prozone effect by this procedure

\begin{tabular}{|c|c|c|c|c|c|c|c|c|c|c|c|}
\hline \multirow{2}{*}{ Serum } & \multicolumn{10}{|c|}{ Test tube dilutions } & \multirow{2}{*}{$\begin{array}{l}\text { End } \\
\text { point }\end{array}$} \\
\hline & $1 / 2$ & $1 / 4$ & $1 / 8$ & $1 / 16$ & $1 / 32$ & $1 / 64$ & $1 / 128$ & $1 / 256$ & $1 / 512$ & $1 / 1024$ & \\
\hline $\begin{array}{c}\text { Undiluted } \\
1 / 5 \\
1 / 10 \\
1 / 20 \\
1 / 100\end{array}$ & $\begin{array}{l}++t \\
++t \\
++t \\
+t+ \\
+\end{array}$ & $\begin{array}{l}++ \\
++ \\
++ \\
++ \\
\pm\end{array}$ & $\begin{array}{l}++ \\
++ \\
++ \\
+\end{array}$ & $\begin{array}{l}++t+ \\
+++ \\
+ \\
-\end{array}$ & $\begin{array}{l}+++t \\
+++ \\
\pm \\
=\end{array}$ & $\begin{array}{l}++ \\
\pm \\
-\end{array}$ & $\begin{array}{l}++ \\
- \\
-\end{array}$ & $\begin{array}{l} \pm \\
- \\
-\end{array}$ & $\begin{array}{l} \pm \\
= \\
- \\
-\end{array}$ & $\begin{array}{l}- \\
- \\
-\end{array}$ & $\begin{array}{l}1 / 512 \\
1 / 320 \\
1 / 320 \\
1 / 160 \\
1 / 400\end{array}$ \\
\hline
\end{tabular}

were combined with anti-A or anti-B serum in various dilutions and the inagglutinable cell counts were obtained with the Denstedt procedure. The data are reported in Table II. Only one of a series of 20 experiments failed to demonstrate a prozone effect in which the undiluted antiserum yielded a higher inagglutinable cell count than dilutions of the same serum made with $0.9 \%$ sodium chloride solution. All sera tested were of human origin and had test-tube titers between 512 and 2,048 , as observed macroscopically. The donors had previously been immunized by injections of the $A$ and B group-specific substances of Witebsky. The finding of the prozone was unexpected on our part although it had been hinted at in the writings of Mollison and by Denstedt. So far as we are aware, the only published data pertinent to this phenomenon are found in a paper by Barnes and Loutit (39). As far as they go, our findings confirm their observations. Several of our antisera were titrated by the usual method of serial dilution in test tubes, but no prozone phenomena could be demonstrated by that procedure (Table III). The conclusion is reached that serial dilution titrations of serum, as usually observed in the test tube, are extremely inaccurate for this purpose and that the method of inagglutinable cell counting furnishes a more delicate means of measurement of agglutinin-agglutinogen reactions. These observations also emphasize the point made by other authors that the blank count of the recipient's inagglutinable cells should be made by a series of dilutions

TABLE IV

Inagglutinable cell counts by the procedure of Denstedt in test-tube mixtures of $O$ and $A$ blood, using anti- $A$ sera

\begin{tabular}{|c|c|c|c|c|c|c|c|c|c|c|c|c|}
\hline \multicolumn{2}{|c|}{ Serum } & \multicolumn{2}{|c|}{ Group O blood } & \multicolumn{2}{|c|}{ Group A blood } & \multicolumn{4}{|c|}{ Blood mixture } & \multicolumn{3}{|c|}{ Inagglutinable cell counts } \\
\hline Lot & $\begin{array}{l}\text { Dilu- } \\
\text { tion }\end{array}$ & Source & $\begin{array}{c}\text { Count } \\
10 \% / \mathrm{mm} .\end{array}$ & Source & $\underset{100 / \mathrm{mm}}{\text { Count }}{ }^{2}$ & $\begin{array}{l}\text { Ratio } \\
\text { O/A }\end{array}$ & $\begin{array}{c}\text { Observed } \\
\text { count } \\
10 \% / \mathrm{mm} .\end{array}$ & $\begin{array}{c}\text { Expected } \\
\text { count } \\
10 \% / \mathrm{mm} .^{3}\end{array}$ & $\begin{array}{c}\text { Corrected } \\
\text { blank } \\
10^{6} / \mathrm{mm} .\end{array}$ & $\begin{array}{c}\text { Observed } \\
\text { count } \\
10 \% / \mathrm{mm}^{8}\end{array}$ & $\begin{array}{c}\text { Expected } \\
\text { count } \\
10^{\circ} / \mathrm{mm} .^{2}\end{array}$ & $\begin{array}{c}\text { Percentage } \\
\text { deviation } \\
\text { from } \\
\text { expected }\end{array}$ \\
\hline $\begin{array}{l}\text { M } \\
\text { M } \\
\text { M } \\
\text { M } \\
\text { M } \\
\text { M } \\
\text { M } \\
\text { M } \\
\text { M } \\
\text { M } \\
\text { M } \\
\text { M } \\
\text { M } \\
\text { M } \\
\text { M } \\
\text { MM2 } \\
\text { MM2 } \\
\text { MM2 } \\
\text { MM2 } \\
\text { MM2 }\end{array}$ & $\begin{array}{l}1 / 1 \\
1 / 1 \\
1 / 1 \\
1 / 1 \\
1 / 1 \\
1 / 1 \\
1 / 1 \\
1 / 1 \\
1 / 1 \\
1 / 5 \\
1 / 1 \\
1 / 5 \\
1 / 5 \\
1 / 1 \\
1 / 5 \\
1 / 5 \\
1 / 5 \\
1 / 5 \\
1 / 5 \\
1 / 5\end{array}$ & $\begin{array}{l}\text { Sheets } \\
\text { Kirk } \\
\text { Gross } \\
\text { Sheets } \\
\text { Gross } \\
\text { Sheets } \\
\text { Sheets } \\
\text { Sheets } \\
\text { Sheets } \\
\text { Sheets } \\
\text { Sheets } \\
\text { Sheets } \\
\text { Sheets } \\
\text { Mont } \\
\text { Mont } \\
\text { Sheets } \\
\text { Sheets } \\
\text { Mont } \\
\text { Sheets } \\
\text { Sheets }\end{array}$ & $\begin{array}{l}5.01 \\
5.71 \\
4.18 \\
4.93 \\
4.16 \\
5.06 \\
4.98 \\
5.46 \\
5.32 \\
5.32 \\
5.21 \\
5.21 \\
5.08 \\
4.93 \\
4.93 \\
5.28 \\
5.28 \\
5.28 \\
5.10 \\
5.20\end{array}$ & $\begin{array}{l}\text { Dahlin } \\
\text { Sint } \\
\text { Scott } \\
\text { Dahlin } \\
\text { Scott } \\
\text { Dahlin } \\
\text { Dahlin } \\
\text { Dahlin } \\
\text { Wheel } \\
\text { Wheel } \\
\text { Dahlin } \\
\text { Dahlin } \\
\text { Ham } \\
\text { Wheel } \\
\text { Wheel } \\
\text { Dahlin } \\
\text { Dahlin } \\
\text { Wheel } \\
\text { Ham } \\
\text { Dahlin }\end{array}$ & $\begin{array}{l}4.46 \\
5.18 \\
5.67 \\
4.71 \\
5.49 \\
4.52 \\
4.36 \\
4.65 \\
4.56 \\
4.56 \\
4.43 \\
4.43 \\
5.80 \\
4.53 \\
4.53 \\
4.51 \\
4.51 \\
4.98 \\
5.77 \\
4.63\end{array}$ & $\begin{array}{l}1 / 11 \\
1 / 11 \\
1 / 11 \\
1 / 11 \\
1 / 11 \\
1 / 11 \\
1 / 11 \\
1 / 11 \\
1 / 11 \\
1 / 11 \\
1 / 11 \\
1 / 11 \\
1 / 10 \\
1 / 11 \\
1 / 11 \\
1 / 11 \\
1 / 7 \\
1 / 11 \\
1 / 11 \\
1 / 11\end{array}$ & $\begin{array}{l}4.58 \\
5.32 \\
5.45 \\
4.78 \\
5.31 \\
4.62 \\
4.43 \\
4.76 \\
4.66 \\
4.66 \\
4.56 \\
4.56 \\
5.65 \\
4.60 \\
4.60 \\
4.58 \\
4.76 \\
5.08 \\
5.69 \\
4.72\end{array}$ & $\begin{array}{l}4.51 \\
5.22 \\
5.53 \\
4.73 \\
5.36 \\
4.57 \\
4.42 \\
4.72 \\
4.63 \\
4.63 \\
4.52 \\
4.52 \\
5.70 \\
4.56 \\
4.56 \\
4.58 \\
4.62 \\
5.00 \\
5.70 \\
4.68\end{array}$ & $\begin{array}{l}.014 \\
.0123 \\
.0227 \\
.020 \\
.0245 \\
.0177 \\
.0136 \\
.0158 \\
.00537 \\
.00132 \\
.0108 \\
.00195 \\
.00603 \\
.00609 \\
.002 \\
.0023 \\
.0023 \\
.00309 \\
.023 \\
.0089\end{array}$ & $\begin{array}{l}.497 \\
.541 \\
.427 \\
.504 \\
.470 \\
.498 \\
.499 \\
.559 \\
.524 \\
.494 \\
.506 \\
.501 \\
.581 \\
.497 \\
.460 \\
.523 \\
.848 \\
.477 \\
.461 \\
.473\end{array}$ & $\begin{array}{l}.456 \\
.520 \\
.381 \\
.448 \\
.378 \\
.460 \\
.453 \\
.496 \\
.483 \\
.483 \\
.473 \\
.473 \\
.508 \\
.448 \\
.448 \\
.480 \\
.753 \\
.480 \\
.464 \\
.473\end{array}$ & $\begin{array}{r}+9.0 \\
+4.0 \\
+12.0 \\
+12.5 \\
+24.0 \\
+8.0 \\
+10.0 \\
+12.0 \\
+8.5 \\
+2.2 \\
+6.9 \\
+5.9 \\
+14.3 \\
+10.9 \\
+2.7 \\
+10.0 \\
+12.0 \\
+0.6 \\
-0.6 \\
0.0\end{array}$ \\
\hline
\end{tabular}


of antiserum so that the optimal concentration of serum may be found with which to perform the tests throughout the experiment.

A series of studies was made on in vitro mixtures of bloods of heterologous groups in which the inagglutinable cell counts were obtained with the Denstedt technique as done in our laboratory. The component bloods of the mixtures were carefully measured in microburettes by one of us and the erythrocyte count of each was estimated in the usual manner by the technician. The proportion of $\mathrm{O}$ blood was always less than that of the other group to resemble the conditions in the recipient after transfusion. The expected inagglutinable cell counts were calculated, making allowance for the blank, and compared with the observed counts. The data are found in Table IV. Comparison of the observed total erythrocyte counts of the blood mixtures with the expected counts incidentally served as a good check on the technician who could not predict the results. It was noted that most of the inagglutinable cell counts were too high, the range being between $+24.0 \%$ and $0.6 \%$.

A study was made of the accuracy of each step in the Denstedt procedure. It was observed that shaking the serum-cell mixture in the long axis of the test tubes in the machine which we employed (not the one advised by Denstedt) resulted in relatively little agitation of cells. The fluid clung to the sides of the tubes and moved only slightly with each cycle of the machine. The possibility was also considered that during a single centrifugation of the serum-cell mixture inagglutinable cells might be entrapped in the agglutinates, making the count too low, or sensitized cells might not make proper surface contact with others on the first centrifugation. Accordingly whole blood mixtures were made in test tubes as before, but the shaking was omitted. Instead, counts were made after centrifuging for one minute at 1,800 revolutions per minute. The bottoms of the tubes containing the blood were then flicked 20 times with the index finger (12a) and the tubes were again centrifuged and counts obtained. The procedure was repeated four times and the results are recorded in Table $\mathrm{V}$.

In none of the tests was the expected inagglutinable cell count approximated after the first centrifugation; the counts were all too high. After the
TABLE $\mathbf{V}$

Inagglutinable cell counts in test-tube mixtures of blood with repeated cycles of centrifugation at 1,800 revolutions per minute and hand shaking

\begin{tabular}{|c|c|c|c|c|c|c|c|}
\hline \multirow{4}{*}{ Serum } & \multirow{4}{*}{ Cells } & \multicolumn{6}{|c|}{ Inagglutinable cell counts } \\
\hline & & \multirow{3}{*}{$\begin{array}{c}\text { Expected } \\
\text { count } \\
10^{6} / \mathrm{mm} .\end{array}$} & \multirow{2}{*}{\multicolumn{4}{|c|}{$\begin{array}{l}\begin{array}{c}\text { Observed counts } \\
100 / \mathrm{mm} .\end{array} \\
\text { entrifuged and hand } \\
\text { shaken }\end{array}$}} & \multirow{3}{*}{$\begin{array}{c}\text { Per cent } \\
\text { deviation } \\
\text { of closest } \\
\text { approxima- } \\
\text { tion (in bold } \\
\text { face) from } \\
\text { expected } \\
\text { count }\end{array}$} \\
\hline & & & & & & & \\
\hline & & & $1 \times$ & $2 \times$ & $3 \times$ & $4 \times$ & \\
\hline $\begin{array}{l}\text { Anti-A } \\
\text { Anti-A } \\
\text { Anti-A } \\
\text { Anti-A } \\
\text { Anti-A } \\
\text { Anti-A } \\
\text { Anti-A } \\
\text { Anti-A } \\
\text { Anti-A } \\
\text { Anti-A } \\
\text { Anti-A } \\
\text { Anti-A } \\
\text { Anti-A } \\
\text { Anti-A } \\
\text { Anti-M } \\
\text { Anti-M } \\
\text { Anti-M } \\
\text { Anti-B } \\
\text { Anti-B } \\
\text { Anti-B } \\
\text { Anti-B } \\
\text { Anti-B } \\
\text { Anti-B } \\
\text { Anti-B }\end{array}$ & $\begin{array}{l}\text { A } \\
\text { A } \\
\text { A } \\
\text { A } \\
\text { A } \\
\text { A } \\
\text { A } \\
\text { A } \\
\text { A } \\
\text { A } \\
\text { A } \\
\text { A } \\
\text { A } \\
\text { A } \\
\text { M } \\
\text { M } \\
\text { M } \\
\text { B } \\
\text { B } \\
\text { B } \\
\text { B } \\
\text { B } \\
\text { B } \\
\text { B }\end{array}$ & $\begin{array}{l}.480 \\
.480 \\
.480 \\
.474 \\
.464 \\
.473 \\
.250 \\
.232 \\
.251 \\
.246 \\
.098 \\
.096 \\
.102 \\
.100 \\
.410 \\
.202 \\
.212 \\
.464 \\
.240 \\
.180 \\
.230 \\
.286 \\
.448 \\
.286\end{array}$ & $\begin{array}{l}.553 \\
.516 \\
.566 \\
.297 \\
.307 \\
.332 \\
.354 \\
.128 \\
.118 \\
.246 \\
.138 \\
.521 \\
.273 \\
.308 \\
.860 \\
.407 \\
.253 \\
.292 \\
.363 \\
.564 \\
.410\end{array}$ & $\begin{array}{l}.485 \\
.480 \\
.481 \\
.470 \\
.460 \\
.472 \\
.240 \\
.254 \\
.257 \\
.259 \\
.112 \\
.109 \\
.113 \\
.101 \\
.388 \\
.214 \\
.198 \\
.584 \\
.352 \\
.185 \\
.269 \\
.339 \\
.492 \\
.348\end{array}$ & $\begin{array}{l}.477 \\
.476 \\
.479 \\
.461 \\
.463 \\
.476 \\
.250 \\
.233 \\
.251 \\
.238 \\
.080 \\
.103 \\
.111 \\
.103 \\
.438 \\
.211 \\
.211 \\
.525 \\
.302 \\
.177 \\
.251 \\
.313 \\
.467 \\
.313\end{array}$ & $\begin{array}{l}.470 \\
.460 \\
.473 \\
.254 \\
.232 \\
.247 \\
.246 \\
.102 \\
.100 \\
.108 \\
.101 \\
.413 \\
.209 \\
.212 \\
.485 \\
.260 \\
.181 \\
.243 \\
.299 \\
.448 \\
.310\end{array}$ & $\begin{array}{c}-0.6 \\
0 \\
+0.2 \\
-0.8 \\
-0.2 \\
0 \\
0 \\
+0.4 \\
0 \\
0 \\
+4.0 \\
+4.1 \\
+5.8 \\
+1.0 \\
+0.7 \\
+3.4 \\
0 \\
+4.5 \\
+8.3 \\
+0.5 \\
+5.6 \\
+5.6 \\
0 \\
+4.8\end{array}$ \\
\hline
\end{tabular}

second centrifugation the best approximation was obtained in four of 14 experiments with anti-A serum. The third cycle was followed by the best results in another five out of 14 with anti-A serum. The closest approximation was obtained after the fourth centrifugation in six of the 14 experiments with anti-A serum, in all three with anti-M serum, and in the seven with anti-B serum. One anti-B serum was used in three experiments and another in four. The same anti-A and anti-M sera were employed throughout. In general, the anti-B sera which we employed gave the poorest results. Not only were larger errors observed with more centrifugation, but it was noted that the agglutinates were less firm and were easily shaken apart although the test-tube titers were considered high $(1,028$ and 2,048$)$.

By the procedure of repeated centrifugation and shaking by hand the deviations from the expected counts were considerably lower than those obtained with the shaking machine in our laboratory, al- 
though there was a tendency to be too high rather than too low. However, the unavoidable error of calculating the expected inagglutinable cell count in these experiments was approximately $\pm 5 \%$. This assumes the limits of error to include twice the standard error of the total cell count and also twice the standard error of the inagglutinable cell counts in Table I. By these criteria all but one value for closest approximation in Table $\mathrm{V}$ fall within the range of probability.

In a few experiments in which the deviation from the expected count was large the procedure was repeated using washed $O$ cells instead of whole blood but the inagglutinable cell counts were not significantly altered. It seems probable that the individual qualities of the antiserum have much to do with the formation of a firm or loose agglutinate and hence the accuracy of the counts.

\section{PROPOSED MODIFICATION OF THE DENSTEDT TECHNIQUE FOR INAGGLUTINABLE CELL COUNTS}

On the basis of the observations so far reported in this paper the following procedures are recommended in the estimation of inagglutinable cell counts. In general these are refinements of the technique developed by Denstedt and his coworkers (32).

\section{General procedure}

From freely bleeding ear lobe punctures draw blood up to the mark 0.5 of a leukocyte pipette and then fill to the mark 11 with $3.2 \%$ trisodium citrate solution $\left(\mathrm{Na}_{3} \mathrm{C}_{6} \mathrm{H}_{5} \mathrm{O}_{7}+2 \mathrm{H}_{2} \mathrm{O}\right)$. Fill a second pipette similarly with blood and citrate solution. Expel the contents of the pipettes completely into clean serologic test tubes $(7.5 \mathrm{~mm}$. by $72 \mathrm{~mm}$. or $13 \mathrm{~mm}$. by $100 \mathrm{~mm}$.). Into dry leukocyte pipettes draw the blood from the tubes up to the mark 1.0 and then fill to the mark 11 with suitable antiserum. Expel the serumblood mixtures into clean dry serologic test tubes. Centrifuge both tubes for one minute at 1,800 revolutions per minute. Remove the tubes from the centrifuge, flick the bottoms of the tubes 20 times with the index finger to break up the agglutinates, and recentrifuge. The exact number of cycles of centrifugation and hand-shaking should be determined by titration of each new lot of anti- serum by the technique to be described. Finally, after gentle shaking of the tube, permit the cells to settle for five seconds and withdraw a sample from the top of the supernatant fluid into a capillary pipette. Charge one side of the counting chamber from the capillary and count the inagglutinated cells in the $9 \mathrm{~mm}^{2}$. Similarly charge the other side of the chamber with the contents from the duplicate tube. The computation is made as follows :

Inagglutinable cells per $\mathrm{mm} .^{3}$

$$
=\left(\text { count in } 9 \mathrm{~mm}^{2}\right) \times \frac{10}{9} \times 22 \times 11 \text {. }
$$

The counts from two pipettes are averaged. If the blood sample has been taken from a test tube to which an anticoagulant has been added, a suitable dilution factor should be included in the equation.

\section{Titration and storage of antisera}

An antiserum should be selected which is highly specific and contains a high titer of agglutinins. The serum should be inactivated at $56^{\circ} \mathrm{C}$. for one hour to destroy complement and prevent the activity of isohemolysins. The optimal dilution of antiserum should be selected by testing the blood of the prospective recipient with serial dilutions of serum, using the technique described in a preceding subsection. The dilutions suggested for preliminary testing are $1 / 1,1 / 5,1 / 10,1 / 20$, and $1 / 100$. If the minimal inagglutinable cell count occurs in one of the dilutions in this range, it is suggested that another series of tests be made with smaller steps of dilution in the optimal range. The determined optimal dilution of antiserum should be employed throughout the experiment with the recipient.

A measured mixture of blood of the prospective donor and recipient should be carefully made in a ratio of about $1 / 11$ and placed in a test tube. The total erythrocyte counts of both bloods should be estimated before mixing. Triplicate samples of the mixture should then be counted for inagglutinable cells after each of four cycles of centrifuging and hand shaking. The closest approximations to the expected inagglutinable cell counts should not deviate by more than $5 \%$. When the results are tabulated three necessary data will be available: $(a)$ the optimal dilution of antiserum to 
be employed, $(b)$ the optimal amount of centrifuging to use in the tests, and $(c)$ the blank inagglutinable cell count of the recipient.

The lot of liquid antiserum finally chosen for a long term study of transfused erythrocyte survival should then be divided into aliquots sufficient for a day's tests and the entire amount should be frozen and kept in that state and the supply for a day should be thawed just before use. This will greatly enhance the stability of the antibodies.

\section{EFFECTS OF PLASMA VOLUME SHIFTS ON COUNTS \\ OF TOTAL ERYTHROCYTES AND INAG-}

\section{GLUTINABLE CELLS}

It has been recognized for many years that the total erythrocyte counts of normal adults undergo variations which are greater than the limits of error in counting. These fluctuations have been attributed to muscular activity, emotional factors, seasonal changes, and shifts in the volume of the blood plasma peripherally or generally. Variations in the rate of hemopoiesis and erythrocyte destruction have also been considered as possible causes. In Figure 1 are plotted the total erythrocyte counts of five normal young adults for a period of about 20 days during which they were engaged in their usual activities about the hospital. Many fluctuations were greater than the limit of error of the method of counting $( \pm 102,000$ per

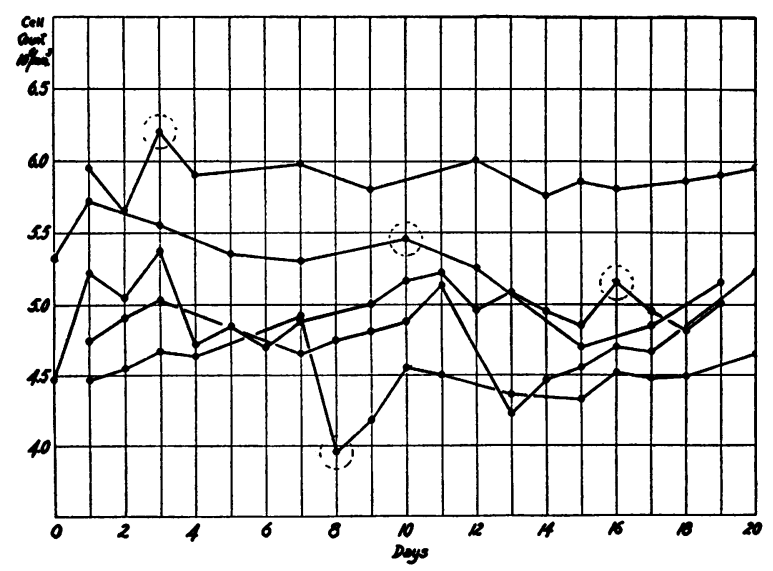

Fig. 1. Fluctuations in the Total Erythrocyte Counts of Five Normal Subjects During a Period of 20 Days

Each plotted graph is the mean of duplicate counts made on the blood from ear lobe punctures. Broken circles are constructed with radii equivalent to twice the standard error of measurement. mm..$^{8}$ ), a few were as much as 750,000 , and one was $1,000,000$ per $\mathrm{mm}^{3}$.

Ever since the work of Ashby the reports and graphs including data on inagglutinable cell counts have shown many fluctuations from a rectilinear curve of decay. The reader is referred to the original papers $(4,10-12,14,15,19-25,27,28)$. In general the authors have not commented upon these findings but have tacitly assumed that they were due to errors in counting. Osborne and Denstedt (32) made an extensive study of the procedure of counting of inagglutinable cells and were unable to discover deficiencies in the technique which completely accounted for variations in the blank inagglutinable cell counts of normal persons. These fluctuations resemble those encountered in recipients in whom inagglutinable cells are acquired by transfusion.

Early in the course of our work the practice was instituted of making estimations of the total erythrocyte count simultaneously with the inagglutinable cell count when transfusion survival studies were made. In all of more than 35 such transfusions to date most of the fluctuations in the inagglutinable cell counts coincided with and were in the same direction as variations in the total erythrocyte counts, and were of approximately similar magnitude. Although there were occasional exceptions, the coincidence was frequent enough to be overwhelmingly significant. Since the great majority of inagglutinable cells in the recipient under these conditions were foreign in source and the long-time study of their decay indicated a fairly constant loss from the body, temporarily observed low inagglutinable cell counts must be caused by increases in the plasma volume of the recipient or a redistribution of cells and plasma in the periphery. Likewise temporary increases in the inagglutinable cell count must be caused by hemoconcentration, peripheral or general, in the recipient since the recipient cannot produce cells of that group.

The observed coincidence between fluctuations in counts of inagglutinable cells and total erythrocytes in the recipient proves two facts: (a) many variations in the inagglutinable cell counts are caused by plasma shifts in the recipient, either peripheral or general, and $(b)$ the parallel fluctuations in the total erythrocyte counts are due to the same phenomenon. 
CALCULATION OF THE RECIPIENT'S ERYTHROCYTE COUNT USING COUNTS OF THE TOTAL CELLS

\section{AND THE INAGGLUTINABLE CELLS}

When blood cells of heterologous group or type are transfused to a recipient they disappear from the circulation in a regular manner. If the counts of inagglutinable cells are plotted on Cartesian coordinates with time in days on the abscissae and the concentration of cells per unit volume on the ordinates, the disappearance curve is rectilinear and the donor's cells are completely lost in about 120 days when there is no abnormal destruction and the transfused cells are normal. Callender, Powell, and Witts $(4,10)$ have studied the significance of this mathematical phenomenon and interpreted it as meaning that each transfused cell lives approximately the same life span, whether in the body of the donor or in the recipient. Fresh transfused blood, therefore, consists of equal numbers of cells of all ages, which complete their full life span in the body of the recipient after transfusion.

It occurred to us that if inagglutinable cells are transfused to a subject and the rate of loss of those cells from the circulation is accurately measured, the inagglutinable cells can be employed as biologic tags and the ratio between the tagged cells and the recipient's cells can be used as an indicator of net gain or deficit of recipient's cells at any time during the survival period of the transfused erythrocytes.

As finally evolved, the procedure consists in the computation of a value for the expected recipient's cell count $(\exp R)$ which is compared with the observed recipient's cell count (obs $R$ ) for the same time. Any significant discrepancy between these two values is indicative of a quantitative gain or deficit of the recipient's cells.

The derivation of the equations is based upon the concept illustrated in Figure 2. This depicts a graph on Cartesian coordinates in which the counts of the recipient's and the donor's erythrocytes are plotted with respect to time in days on the abscissae and concentrations of cells per $\mathrm{mm} .^{3}$ on the ordinates. The time $\mathrm{N}$ is the total number of days from the beginning of the study until the tagged cells have disappeared from the circulation. Any specific time during the experiment may be denoted by $n$ days from the beginning.

Let us assume that, during the entire study, (a) the recipient neither gains nor loses in the total number of his erythrocytes and $(b)$ that these red cells are not subject to any plasma shifts. Then the count of the recipient's cells per unit volume will be constant and the graphic representation will be a rectangle. The concentration will be the observed count taken at an arbitrary reference point at the beginning of the study and designated as the reference recipient's cell count (ref $R$ ). But the donor's cells constantly diminish in concentration per unit volume from the beginning of the study when the reference donor's cell count (ref $D$ ) was taken. Since the disappearance curve of the tagged cells is rectilinear, the graph of the inagglutinable cell counts describes a right triangle.

Then at any time $n$ days on the graph the following relation occurs:

(1) $\frac{\mathrm{Dn}}{\operatorname{ref} \mathrm{D}}=\frac{\mathrm{N}-\mathrm{n}}{\mathrm{N}} ; \quad \mathrm{Dn}=\operatorname{ref} \mathrm{D} \times \frac{\mathrm{N}-\mathrm{n}}{\mathrm{N}}$.

(Assumptions: $(a)$ the disappearance curve of the donor's cells is rectilinear, $(b)$ the total number of the recipient's cells has not changed during the study, and (c) there have been no plasma shifts to change cell concentrations.)

If at $\mathbf{n}$ time the observed values for counts of the cells of the recipient and donor (obs $R$ and $o b s D$ ) have been altered from the theoretical only by plasma shifts, then:

$$
\frac{\text { obs } R}{\text { obs } D}=\frac{\text { ref } R}{D n} ; \quad \text { obs } R=\text { obs } D \times \frac{\text { ref } R}{D n} .
$$

The ratio of donor's cells to recipient's cells at that time has not been altered by the plasma shift and the assumptions involved are $(a)$ the disappearance curve of donor's cells is rectilinear, and $(b)$ the total number of recipient's cells in the body has not changed during the time under consideration.

For example, suppose that the count of the recipient's cells at the reference time (ref $R$ ), and also at time $n$, is $5,000,000$ per $\mathrm{mm}^{3}$ and the count of the donor's cells at time $n(D n)$, as computed from $\mathrm{Dn}=\operatorname{ref} \mathrm{D} \times \frac{\mathrm{N}-\mathrm{n}}{\mathrm{N}}$, is $1,000,000$ per $\mathrm{mm} .^{3}$. If there is no difference in the plasma volume at the reference time and time $n$, then both ref $R$ and obs $R$ are 5.0 and $\mathrm{Dn}=$ obs $\mathrm{D}$. The proportion of recipient's to donor's cells is $\frac{\text { obs } R}{\text { obs } D}=\frac{\text { ref } R}{D n}=\frac{5}{1}$. Suppose at time $\mathrm{n}$ that the plasma volume has halved although the total number of recipient's cells in the body is the same as at reference time. Then obs $R=10.0$, obs $D=2.0$ but ref $R=5.0$ and $D n=1.0$. We have then $\frac{\text { obs } R}{\text { obs } D}=\frac{\text { ref } R}{D n}$ or $\frac{10.0}{2.0}=\frac{5.0}{1.0}=\frac{5}{1}$. The ratio between the recipient's and donor's cells has not changed although the observed values have been doubled by the hemoconcentration.

Substituting ref $D \times \frac{N-n}{N}$ from (1) for $D n$ in (2), we 


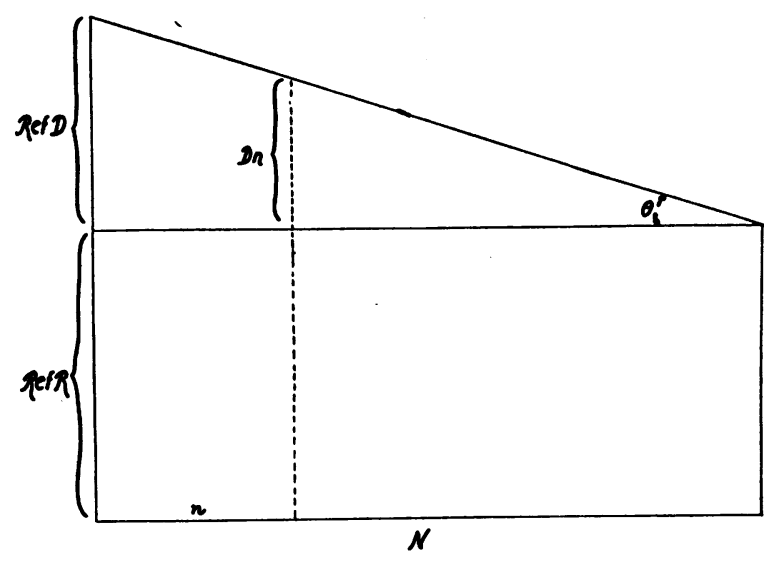

Fig. 2. Constructed Figure Representing Data From a Hypothetical Transfusion Experiment Plotted on Cartesian Coordinates, Assuming There are No Plasma Shifts and That the Total Number of Recipient's Cells in the Body Remains Constant DuRing The Study

The value ref $D$ is the observed count of donor's cells at an arbitrary reference time near the beginning of the experiment. The value ref $R$ is the observed count of recipient's cells taken at the same reference time. The symbol $\mathrm{N}$ stands for the number of days after the reference time at which the inagglutinable cells disappear from the circulation. Any time $n$ during the study is the number of days which have elapsed after the reference time. The inagglutinable cell count $\mathrm{Dn}$ is the predictable value at time $n$; the value becomes smaller daily during the study.

have

$$
\text { obs } R=\operatorname{obs} D \times \frac{\operatorname{ref} R}{\operatorname{ref} D} \times \frac{N}{N-n} .
$$

Since the disappearance curve of $D$ has been shown to be rectilinear by plotting all the observed values of obs $D$, and since plasma shifts have been compensated for in (2), the equation (3) will be true if there has been no change in the total number of recipient's cells in the body to alter the ratio $\left(\frac{\text { ref } R}{D n}\right)$. If there has been a gain or deficit of recipient's cells, (3) will not be an equality. To test whether equality does exist the unknown $\exp R$ (for expected recipient's cell count) is substituted for obs $R$ and the equation solved for $\exp R$ :

$$
\exp R=\operatorname{obs} D \times \frac{\operatorname{ref} R}{\operatorname{ref} D} \times \frac{N}{N-n} .
$$

If the computed value $\exp R$ coincides, within the limits of error, with the measured value obs $R$, we have proved that there has been no gain or deficit of recipient's erythrocytes in the body. A significant discrepancy between the observed and expected values, however, can be employed as a measure of gain or deficit of the recipient's cells.
For example, suppose that at time $n$, in addition to a shift resulting in halving the plasma volume, there has been an actual increase of $20 \%$ in the recipient's cells in the body. If there had been no plasma shift the recipient's cell count would have increased from $5,000,000$ per mm..$^{8}$ to $6,000,000$. With the plasma halved, the concentration of recipient's cells would be $12,000,000$ per mm. ${ }^{3}$. Expression (2) would then appear as $12.0=2.0 \times \frac{5.0}{1.0}$ or $12=10$, an obvious impossibility. Solving for exp $R$ in (4), however, we have $\exp R=2.0 \times \frac{5.0}{1.0}=10.0$. And obs $R-\exp R$ $=12.0-10.0=2.0$. This means that the increase in number of recipient's cells has been 2,000,000 per mm..$^{3}$ or an augmentation of $20 \%$, regardless of plasma shifts.

In applying equation (4) to observed data in a transfusion survival study a reference time is arbitrarily selected sufficiently long after the transfusion of tagged cells to allow for complete mixing. This is probably within 30 minutes after the termination of the infusion but we have found that 24 hours afterward is quite convenient. The observed recipient's cell count and the observed donor's cell count at that time are taken as the reference values ref $R$ and ref $D$, respectively. The time in days from the reference time until complete disappearance of the donor's cells from the circulation is taken as $N$. At any time under consideration during the study the number of days after the reference time is designated as $\mathrm{n}$. The observed values for counts at time $\mathrm{n}$ are termed obs $T$, obs $R$, and obs $D$. The abbreviation obs $T$ means the total erythrocyte count in mm..$^{3}$. Actually obs $T$ and obs $D$ are measured values taken from the counting chamber and obs $R$ is obtained from the expression: obs $R=$ obs $T$ - obs $D$. The standard error of obs $D$ is much smaller than that of obs $T$ so that, for simplicity, the standard error of $o b s R$ is assumed to be equal to that of obs $T$.

\section{Computation of the standard error of $\exp \mathrm{R}$}

To compare values for obs $R$ and $\exp R$ the standard error of the computed value $\exp R$ must obviously be determined to demonstrate significant discrepancies. Equation (4) contains many measured values, each with its standard error. The standard error of the expected recipient's cell count $(S E \exp R)$ is derived from the general equations for the products and quotients of standard errors:

$$
\begin{aligned}
& \left(\frac{\operatorname{SE} \overline{\mathrm{x}}_{1} \cdot \operatorname{SE} \overline{\mathrm{x}}_{2} \cdots \mathrm{SE} \overline{\mathrm{x}}_{\mathrm{n}}}{\overline{\mathrm{X}}_{1} \cdot \overline{\mathrm{X}}_{2} \cdots \overline{\mathrm{X}}_{\mathrm{n}}}\right)^{2}=\left(\frac{\mathrm{SE} \overline{\mathrm{x}}_{1}}{\overline{\mathrm{X}}_{1}}\right)^{2} \\
& +\left(\frac{\mathrm{SE} \overline{\mathrm{x}}_{2}}{\overline{\mathrm{X}}_{2}}\right)^{2}+\cdots\left(\frac{\mathrm{SE} \overline{\mathrm{x}}_{\mathrm{n}}}{\overline{\mathrm{X}}_{\mathrm{n}}}\right)^{2} \\
& \operatorname{SE}\left(\overline{\mathbf{x}}_{1} \cdot \overline{\mathbf{x}}_{2} \cdots \overline{\mathbf{x}}_{\mathrm{n}}\right)=\overline{\mathrm{X}}_{1} \cdot \overline{\mathrm{X}}_{2} \ldots \\
& \times \bar{X}_{n} \sqrt{\left(\frac{S E \bar{x}_{1}}{\bar{X}_{1}}\right)^{2}+\left(\frac{S E \bar{x}_{2}}{\bar{X}_{2}}\right)^{2}+\cdots\left(\frac{S E \bar{x}_{n}}{\bar{X}_{n}}\right)^{2}}
\end{aligned}
$$


(6) $\left(\frac{\mathrm{SE} \frac{\overline{\mathrm{x}}^{1}}{\overline{\mathrm{X}}_{2}}}{\overline{\mathrm{X}}_{1}}\right)^{2}=\left(\frac{\mathrm{SE} \overline{\mathrm{x}}_{1}}{\overline{\mathrm{X}}_{2}}\right)^{2}+\left(\frac{\mathrm{SE} \overline{\mathrm{X}}_{2}}{\overline{\mathrm{X}}_{2}}\right)^{2}$

$$
\operatorname{SE} \frac{\bar{x}_{1}}{\bar{x}_{2}}=\frac{\bar{X}_{1}}{\bar{X}_{2}} \sqrt{\left(\frac{S E \bar{x}_{1}}{\bar{X}_{1}}\right)^{2}+\left(\frac{S E \bar{x}_{2}}{\bar{X}_{2}}\right)^{2}} .
$$

Applying (5) and (6) to the expression $\exp R=$ obs $D$ $\times \frac{\text { ref } R}{\text { ref } D} \times \frac{N}{N-n}$ we have

(7) $\mathrm{SE} \exp \mathrm{R}=\exp \mathrm{R}\left\{\left(\frac{\mathrm{SE} \text { ref } \mathrm{R}}{\text { ref } \mathrm{R}}\right)^{2}+\left(\frac{\mathrm{SE} \text { obs } \mathrm{D}}{\text { obs } \mathrm{D}}\right)^{2}\right.$

$$
+\left(\frac{\text { SE ref } D}{\operatorname{ref} D}\right)^{2}+\left(\frac{\mathrm{SE} \frac{N}{N-n}}{\frac{N}{N-n}}\right)^{2}
$$

The last term may be expanded for solution as follows, assuming $\mathrm{SE} \mathbf{n}=0$ :

$$
S E \frac{N}{N-n}=\frac{N \pm S E(N)}{N \pm S E(N)-n}-\frac{N}{N-n} .
$$

The standard error of $\mathbf{n}$ can be neglected:

$$
\begin{aligned}
\frac{\mathrm{SE} \frac{N}{N-n}}{\frac{N}{N-n}}=\frac{\frac{N \pm S E(N)}{N \pm S E(N)-n}-\frac{N}{N-n}}{\frac{N}{N-n}} \\
=\frac{(N \pm S E N)(N-n)}{(N \pm S E N-n) N}-1 .
\end{aligned}
$$

The final form of (7) is then

(10) $\mathrm{SE} \exp \mathrm{R}=\exp \mathrm{R}\left\{\left(\frac{\mathrm{SE} \text { ref } \mathrm{R}}{\text { ref } \mathrm{R}}\right)^{2}\right.$

$$
\begin{aligned}
& +\left(\frac{\mathrm{SE} \mathrm{obs} D}{\text { obs } D}\right)^{2}+\left(\frac{\mathrm{SE} \text { ref } \mathrm{D}}{\operatorname{ref} \mathrm{D}}\right)^{2} \\
& \left.+\left[\frac{(\mathrm{N} \pm \mathrm{SE} N)(\mathrm{N}-\mathrm{n})}{(\mathrm{N} \pm \mathrm{SE} N-\mathrm{n}) \mathrm{N}}-1\right]^{2}\right\}^{3}
\end{aligned}
$$

\section{Experimental applications of the method}

The following are examples of the application of equations (4) and (10) in actual studies. Twice the standard error of measurement on either side of the observed or computed value is employed throughout.

In Tables VI and VII are the data on two transfusion experiments performed at different times on the same subject, a normal male medical student. These data are plotted in Figures 3 and 4 respectively. The recipient belonged to group $\mathrm{A}$ and in each case was transfused with $500 \mathrm{ml}$. of group $\mathrm{O}$ blood from normal donors. In the first study (Table VI and Figure 3 ) the transfused cells disappeared from the circulation on about the 119th day; in the second study (Table VII and Figure 4) the tagged cells were measured only

\begin{tabular}{|c|c|c|c|c|c|c|}
\hline $\begin{array}{l}\text { Time } \\
\text { after } \\
\text { trans- } \\
\text { fusion }\end{array}$ & $\mathbf{N}-\mathrm{n} \mid$ & $\begin{array}{c}\text { Observed } \\
\text { total } \\
\text { cell } \\
\text { count } \\
\text { obs } T \\
106 / \mathrm{mm} .\end{array}$ & $\begin{array}{c}\text { Observed } \\
\text { donor's } \\
\text { cell } \\
\text { count } \\
\text { obs } D \\
10 \% / \mathrm{mm} .\end{array}$ & $\begin{array}{c}\text { Observed } \\
\text { recipient's } \\
\text { cell } \\
\text { count } \\
\text { obs } R \\
108 / \mathrm{mm} .\end{array}$ & $\begin{array}{c}\text { Expected } \\
\text { recipient's } \\
\text { cell } \\
\text { count } \\
\text { exp } R \\
10 \% / \mathrm{mm} .\end{array}$ & $\begin{array}{l}\text { Twice the } \\
\text { standard } \\
\text { error of } \\
\exp R \\
10^{\circ} / \mathrm{mm} .\end{array}$ \\
\hline $\begin{array}{c}\text { days } \\
1 \\
2 \\
3 \\
4 \\
5 \\
6 \\
7 \\
8 \\
9 \\
10 \\
11 \\
12 \\
13 \\
16 \\
17 \\
22 \\
24 \\
25 \\
26 \\
27 \\
29 \\
30 \\
32 \\
34 \\
36 \\
39 \\
41 \\
43 \\
46 \\
47 \\
48 \\
51 \\
52 \\
53 \\
54 \\
55 A \\
55 B \\
57 \\
61 \\
65\end{array}$ & $\begin{array}{c}\text { days } \\
119 \\
118 \\
117 \\
116 \\
115 \\
114 \\
113 \\
112 \\
111 \\
110 \\
109 \\
108 \\
107 \\
104 \\
103 \\
98 \\
96 \\
95 \\
94 \\
93 \\
91 \\
90 \\
88 \\
86 \\
84 \\
81 \\
79 \\
77 \\
74 \\
73 \\
72 \\
69 \\
68 \\
67 \\
66 \\
65 \\
65 \\
63 \\
59 \\
55\end{array}$ & $\begin{array}{l}\mathbf{5 . 5 0} \\
\mathbf{5 . 5 7} \\
\mathbf{5 . 5 6} \\
4.95 \\
4.82 \\
\mathbf{4 . 4 8} \\
\mathbf{5 . 2 2} \\
\mathbf{5 . 0 6} \\
\mathbf{5 . 3 8} \\
4.71 \\
4.83 \\
4.72 \\
4.89 \\
\mathbf{5 . 0 0} \\
\mathbf{5 . 1 6} \\
4.94 \\
4.85 \\
4.94 \\
4.81 \\
\mathbf{5 . 0 1} \\
\mathbf{4} .84 \\
\mathbf{5 . 0 8} \\
\mathbf{5 . 1 0} \\
\mathbf{5 . 1 0} \\
\mathbf{5 . 1 2} \\
\mathbf{5 . 4 1} \\
\mathbf{5 . 5 4} \\
\mathbf{5 . 5 8} \\
\mathbf{5 . 5 8} \\
\mathbf{5 . 6 6} \\
\mathbf{5 . 7 6} \\
\mathbf{5 . 6 5} \\
\mathbf{5 . 5 4} \\
\mathbf{5 . 3 4} \\
\mathbf{5 . 2 3} \\
\mathbf{5 . 5 4} \\
\mathbf{5 . 0 8} \\
\mathbf{5 . 1 6} \\
\mathbf{5 . 1 4} \\
\mathbf{5 . 1 8}\end{array}$ & $\begin{array}{l}.380 \\
.430 \\
.400 \\
.375 \\
.364 \\
.393 \\
.390 \\
.382 \\
.351 \\
.331 \\
.320 \\
.315 \\
.308 \\
.357 \\
.356 \\
.310 \\
.300 \\
.307 \\
.285 \\
.302 \\
.286 \\
.287 \\
.284 \\
.278 \\
.281 \\
.281 \\
.270 \\
.263 \\
.257 \\
.248 \\
.292 \\
.242 \\
.211 \\
.199 \\
.186 \\
.225 \\
.175 \\
.177 \\
.172 \\
.203\end{array}$ & $\begin{array}{l}5.12 \\
5.14 \\
5.16 \\
4.57 \\
4.46 \\
4.09 \\
4.83 \\
4.68 \\
5.03 \\
4.38 \\
4.51 \\
4.41 \\
4.58 \\
4.64 \\
4.80 \\
4.63 \\
4.55 \\
4.63 \\
4.53 \\
4.71 \\
4.55 \\
4.79 \\
4.82 \\
4.82 \\
4.84 \\
5.13 \\
5.27 \\
5.32 \\
5.32 \\
5.41 \\
5.47 \\
5.41 \\
5.33 \\
5.14 \\
5.04 \\
5.32 \\
4.91 \\
4.98 \\
4.97 \\
4.98\end{array}$ & $\begin{array}{l}5.14 \\
4.82 \\
4.55 \\
4.46 \\
4.86 \\
4.86 \\
4.81 \\
4.45 \\
4.24 \\
4.14 \\
4.11 \\
4.05 \\
4.84 \\
4.87 \\
4.46 \\
4.40 \\
4.55 \\
4.27 \\
4.57 \\
4.43 \\
4.49 \\
4.55 \\
4.55 \\
4.71 \\
4.89 \\
4.81 \\
4.81 \\
4.89 \\
4.79 \\
5.71 \\
4.94 \\
4.37 \\
4.18 \\
3.97 \\
4.88 \\
3.79 \\
3.96 \\
4.11 \\
5.20\end{array}$ & $\begin{array}{l}.139 \\
.134 \\
.131 \\
.141 \\
.141 \\
.141 \\
.134 \\
.129 \\
.128 \\
.128 \\
.127 \\
.152 \\
.152 \\
.153 \\
.153 \\
.163 \\
.158 \\
.169 \\
.171 \\
.171 \\
.185 \\
.185 \\
.206 \\
.228 \\
.235 \\
.244 \\
.268 \\
.270 \\
.324 \\
.306 \\
.283 \\
.278 \\
.273 \\
.336 \\
.270 \\
.294 \\
.337 \\
.466\end{array}$ \\
\hline
\end{tabular}
for 97 days but the point of disappearance was estimated to be about 140 days. In both most of the fluctuations in the total cell counts (obs $T$ ) were

TABLE VI

Data of experiment in Figure 3 on transfusion of normal group $O$ blood to normal group $A$ recipient

Reference day $=$ two days after transfusion; $N$ $=118 \pm 10$; ref $D=.430 \pm .010 ;$ ref $R=5.14 \pm .120$; $2 \times \mathrm{SE}$ obs $\mathrm{T}=.120 ; 2 \times \mathrm{SE}$ obs $\mathrm{D}=.010 ; 2 \times \mathrm{SE}$ obs $\mathrm{R}=.120$. 


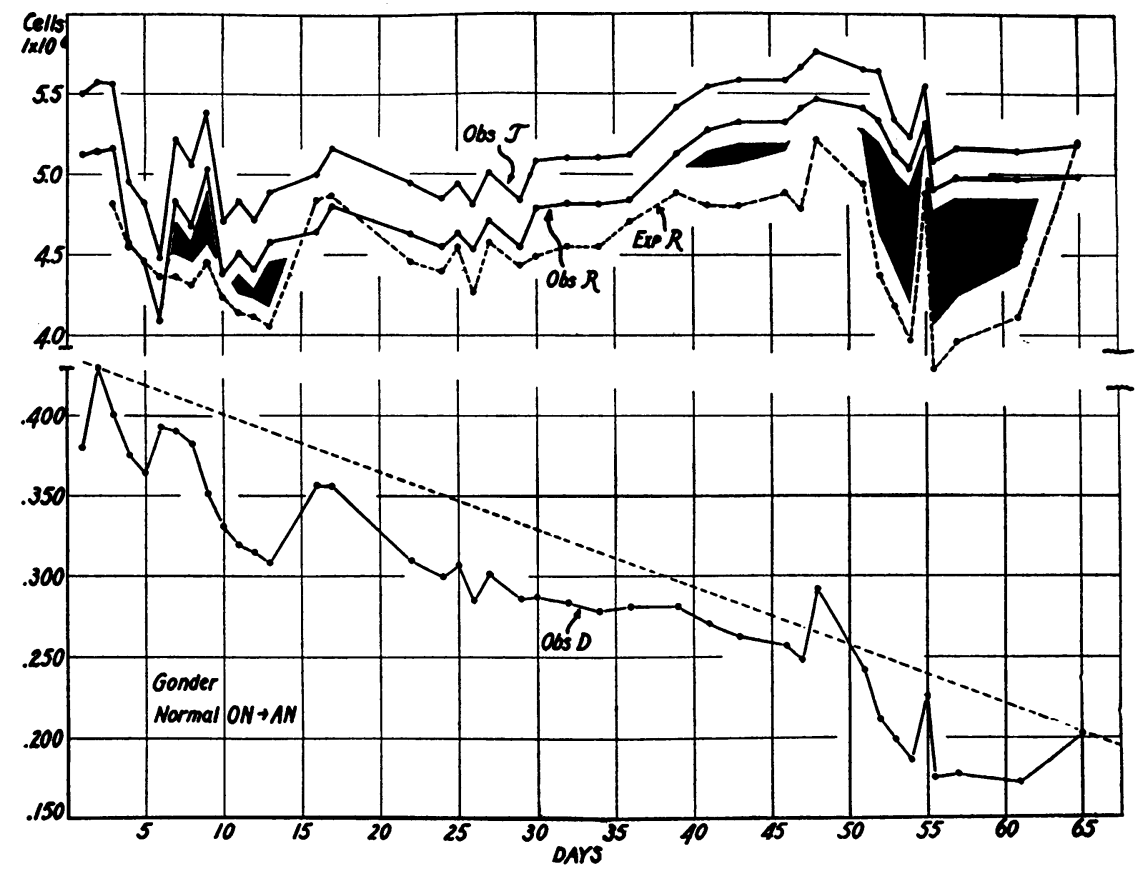

Fig. 3. Data from a Normal Subject Belonging to Group a Who Was TransFUSED WITH 500 ML. of Group O Blood from a Normal Donor

Plotted on the upper graph are the values for the total erythrocyte counts (obs $T$ ), the observed recipient's cell counts (obs $R$ ), and the expected recipient's cell counts $(\exp R)$. The lower graph is constructed on a scale ten times as great and contains the observed inagglutinable cell counts (obs $D$ ). Prolongation of the broken line intersects the $\mathrm{X}$ axis at 120 days after transfusion. Note the parallel fluctuations in the values for obs $T$ and $o b s D$, most of which may be attributed to plasma shifts. The black areas from the seventh to the 14th day, from the 40th to the 46th day, and from the 51st to the 62nd day represent significant discrepancies between $\exp R$ and $o b s R$. In all cases obs $R$ is the greater so that these findings measure the net gain of recipient's cells during those periods. The white border between the plotted values and the black areas are constructed with a width of twice the standard error of measurement or computation. Note the dips in the values for obs $D$ when there is a net gain in the recipient's cells. These are attributed to increases in total blood volume from the additional recipient's cells (see text).

paralleled by variations in the counts of the inagglutinable cells (obs $D$ ) of similar magnitude and in the same direction. Furthermore these fluctuations frequently covered a period of several days with several observed values coinciding with a general trend so that chance variation as an explanation is extremely unlikely. When the values for $\exp R$ (expected recipient's cell count) are compared with those of $o b s R$ (observed recipient's cell count) it is found that there was a significant gain in the recipient's cell count between the sixth and the ninth day after transfusion in the first study and between the fourth and the 13th day in the second study. These were demonstrated by obs $R$ exceeding $\exp R$ by more than twice the standard error for each of the two values. In the first study there was another period between the 50th and the 62nd day when there was a significant gain in recipient's cells. Whenever there was a gain in recipient's cells a dip in the curve of inagglutinable cell counts (obs $D$ ) occurred.

An example of the measurement of a spectacular gain in recipient's cells is presented in the data in Table VIII and Figure 5 from a transfusion study in which group $\mathrm{O}$ cells, washed in isotonic sodium chloride solution, were transfused to a female patient of group A, who had paroxysmal nocturnal hemoglobinuria. At the time of transfusion her 
TABLE VII

Data of experiment in Figure 4 on transfusion of normal group $O$ blood to normal group $A$ recipient

\begin{tabular}{|c|c|c|c|c|c|c|}
\hline $\begin{array}{l}\text { Time } \\
\text { after } \\
\text { trans- } \\
\text { fusion }\end{array}$ & $\mathbf{N}-\mathbf{n}$ & $\begin{array}{c}\text { Observed } \\
\text { total } \\
\text { cell } \\
\text { count } \\
\text { obs } T \\
10 \% / \mathrm{mm} .\end{array}$ & $\begin{array}{c}\text { Observed } \\
\text { donor's } \\
\text { cell } \\
\text { count } \\
\text { obs } D \\
10 \% / \mathrm{mm} .\end{array}$ & $\begin{array}{l}\text { Observed } \\
\text { recipient's } \\
\text { cell } \\
\text { count } \\
o b s R \\
108 / \mathrm{mm} .^{2}\end{array}$ & $\begin{array}{c}\text { Expected } \\
\text { recipient's } \\
\text { cell } \\
\text { count } \\
\text { exp } R \\
10^{\circ} / \mathrm{mm} .\end{array}$ & $\begin{array}{l}\text { Twice the } \\
\text { standard } \\
\text { error of } \\
\quad \exp R \\
10^{\circ} / \mathrm{mm} .\end{array}$ \\
\hline days & days & & & & & \\
\hline $\begin{array}{r}1 \\
2 \\
3 \\
4 \\
5 \\
6 \\
13 \\
18 \\
24 \\
27 \\
51 \\
97\end{array}$ & $\begin{array}{r}139 \\
138 \\
137 \\
136 \\
135 \\
134 \\
127 \\
122 \\
116 \\
113 \\
89 \\
43\end{array}$ & $\begin{array}{l}5.29 \\
5.23 \\
5.25 \\
4.96 \\
4.85 \\
4.72 \\
4.89 \\
5.19 \\
4.76 \\
4.94 \\
4.97 \\
5.14\end{array}$ & $\begin{array}{l}.468 \\
.459 \\
.451 \\
.436 \\
.379 \\
.350 \\
.371 \\
.408 \\
.357 \\
.373 \\
.281 \\
.154\end{array}$ & $\begin{array}{l}4.82 \\
4.77 \\
4.78 \\
4.52 \\
4.47 \\
4.37 \\
4.52 \\
4.78 \\
4.40 \\
4.57 \\
4.69 \\
4.99\end{array}$ & $\begin{array}{l}4.85 \\
4.78 \\
4.75 \\
4.62 \\
4.04 \\
3.77 \\
4.21 \\
4.82 \\
4.43 \\
4.76 \\
4.55 \\
5.15\end{array}$ & $\begin{array}{l}.201 \\
.198 \\
.199 \\
.196 \\
.181 \\
.174 \\
.193 \\
.222 \\
.212 \\
.228 \\
.368 \\
.783\end{array}$ \\
\hline
\end{tabular}

Reference day $=$ one day after transfusion; $\mathrm{N}$ $=140 \pm 10 ;$ ref $D=.468 \pm .010$; ref $R=4.82 \pm .120$; $2 \times \mathrm{SE}$ obs $\mathrm{T}=.120 ; 2 \times \mathrm{SE}$ obs $\mathrm{D}=.010 ; 2 \times \mathrm{SE}$ obs $\mathrm{R}=.120$.

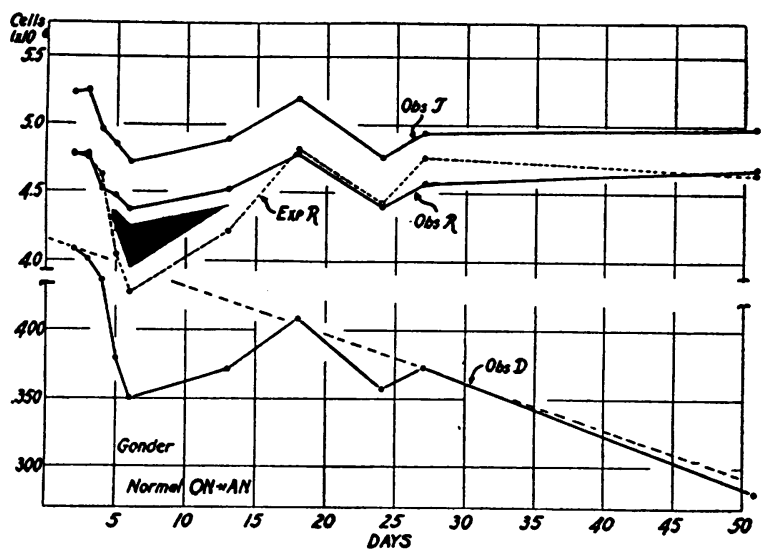

Fig. 4. Data from a Normal Subject Belonging to Group a Who Was Transfused with $500 \mathrm{ML}$. of Blood of Group O From a Normal Donor

In the upper graph are plotted values for the observed total erythrocyte counts (obs $T$ ), the observed recipient's cell counts (obs $R$ ), and expected recipient's cell counts $(\exp R)$. The lower graph is constructed on a scale ten times greater and contains the observed inagglutinable cell counts (obs $D$ ). The broken line intersects the $\mathrm{X}$ axis at 140 days. The black area represents a significant gain in recipient's cells from the fourth to the 13th day after transfusion. The corresponding sharp dip in the inagglutinable cells is caused by the increase in blood volume from the additional recipient's cells, concurrent with an increase in plasma volume. The subject is the one from whom another study is presented in Figure 3.

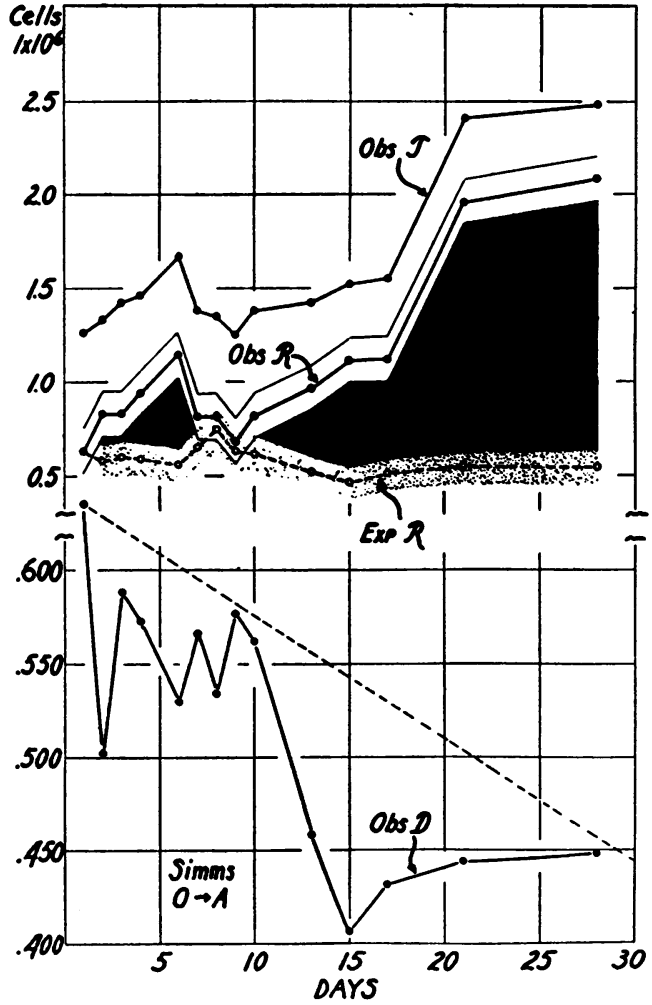

Fig. 5. Data from a Patient with Paroxysmal Nocturnal Hemoglobinuria Belonging to Group A Who Received a Transfusion of Washed Erythrocytes of Group O from a Normal Donor

The upper graph contains plotted values for obs $T$, obs $R$, and $\exp R$. The lower graph, on a scale ten times as great, contains plotted values for obs $D$ and the broken line of the slope which intersects the $\mathrm{X}$ axis at 100 days. The clear zone around $o b s R$ and the stippled zone around $\exp R$ indicate twice the standard error on either side of the values. The black areas indicate significant discrepancies between the observed values for the recipient's cell counts and the expected values. There is an initial increase in recipient's cells after transfusion, comparable to that observed in normal subjects. A secondary increase in recipient's cells follows until the end of the study, 28 days, when the net increase was measured as $279 \%( \pm 23 \%)$. Just before transfusion $75 \%$ of the recipient's erythrocytes were reticulated and there was constant hemoglobinemia and paroxysmal hemoglobinuria. After transfusion the clinical appearance rapidly improved and the hemoglobin in plasma and urine was less. Splenectomy had been performed some months before the study. Notice the deep dip in the values for the inagglutinable cell counts coincident with the gain in the recipient's cells, indicating a great expansion in blood volume. 
TABLE VIII

Data of experiment in Figure 5 on transfusion of washed normal group $O$ cells to group $A$ recipient with paroxysmal nocturnal hemoglobinuria

\begin{tabular}{|c|c|c|c|c|c|c|}
\hline $\begin{array}{l}\text { Time } \\
\text { after } \\
\text { trans- } \\
\text { fusion }\end{array}$ & $N-n \mid$ & $\begin{array}{c}\text { Observed } \\
\text { total } \\
\text { cell } \\
\text { count } \\
\text { obs } T \\
106 / \mathrm{mm} .\end{array}$ & $\begin{array}{c}\text { Observed } \\
\text { donor's } \\
\text { cell } \\
\text { count } \\
\text { obs D } \\
10^{6} / \mathrm{mm}^{8}\end{array}$ & $\begin{array}{c}\text { Observed } \\
\text { recipient's } \\
\text { cell } \\
\text { count } \\
\text { obs } R \\
106 / \mathrm{mm} .3\end{array}$ & $\begin{array}{c}\text { Expected } \\
\text { recipient's } \\
\text { cell } \\
\text { count } \\
\exp R \\
10^{\circ} / \mathrm{mm} .3\end{array}$ & $\begin{array}{l}\text { Twice the } \\
\text { standard } \\
\text { error of } \\
\exp R \\
10 \% \mathrm{~mm} .\end{array}$ \\
\hline days & days & & & & & \\
\hline 1 & 99 & 1.26 & .635 & .625 & .638 & .102 \\
\hline 2 & 98 & 1.33 & .502 & .828 & .508 & .081 \\
\hline 3 & 97 & 1.42 & .588 & .832 & .600 & .096 \\
\hline 4 & 96 & 1.46 & .572 & .933 & .592 & .094 \\
\hline 6 & 94 & 1.0 & .530 & 1.140 & .560 & .089 \\
\hline 7 & 93 & 1.38 & .566 & .814 & .605 & .096 \\
\hline 0 & $0 ?$ & 1.35 & .534 & .816 & .575 & .092 \\
\hline 0 & 91 & 1.2 & .577 & .673 & .630 & .100 \\
\hline 10 & 90 & 1.3 & .562 & .81 & .6 & .099 \\
\hline 13 & 87 & 1.42 & .458 & .962 & .523 & .084 \\
\hline 15 & & 1.52 & .405 & 1.115 & .473 & .076 \\
\hline 17 & & 1. & .43 & 1.1 & .5 & .083 \\
\hline 21 & 7 & 2. & .4 & 1.9 & .5 & .090 \\
\hline 28 & 72 & 2.48 & .398 & 2.082 & .548 & .090 \\
\hline
\end{tabular}

Reference day $=$ day of transfusion; $N=100 \pm 10$ ref $\mathrm{D}=0.632 \pm 0.010 ;$ ref $\mathrm{R}=0.632 \pm .100 ; 2 \times \mathrm{SE}$ obs $\mathrm{T}=.100 ; 2 \times \mathrm{SE}$ obs $\mathrm{D}=.010 ; 2 \times \mathrm{SE}$ obs $\mathrm{R}$ $=.100$.

erythrocyte count was approximately $1,000,000$ per $\mathrm{mm}^{3}$ and about $75 \%$ of the cells were reticulocytes. There was continuous hemoglobinemia and hemoglobin appeared in the urine nocturnally. After transfusion the total red cell count (obs $T$ ) had risen to $2,500,000$ per $\mathrm{mm}^{3}$ by the 28 th day; the hemoglobinuria and hemoglobinemia had improved immensely. It was estimated that the inagglutinable cells were disappearing at a rate compatible with survival for 100 days. Com-

TABLE IX

Data of experiment in Figure 6 on transfusion of group $O$ blood from Cooley's trait to group $A$ recipient with Cooley's anemia

\begin{tabular}{|c|c|c|c|c|c|c|}
\hline $\begin{array}{l}\text { Time } \\
\text { after } \\
\text { trans- } \\
\text { fusion }\end{array}$ & $\mathbf{N}-\mathrm{n}$ & $\begin{array}{c}\text { Observed } \\
\text { total } \\
\text { cell } \\
\text { count } \\
\text { obs } T \\
10 \% / \mathrm{mm} .3\end{array}$ & $\begin{array}{c}\text { Observed } \\
\text { donor's } \\
\text { cell } \\
\text { count } \\
\text { obs } D \\
10 \% / \mathrm{mm} .3\end{array}$ & $\begin{array}{l}\text { Observed } \\
\text { recipient's } \\
\text { cell } \\
\text { count } \\
\text { obs } R \\
108 / \mathrm{mm} .\end{array}$ & $\begin{array}{c}\text { Expected } \\
\text { recipient's } \\
\text { cell } \\
\text { count } \\
\exp R \\
100 \% \mathrm{~mm} \cdot \mathrm{s}\end{array}$ & $\begin{array}{l}\text { Twice the } \\
\text { standard } \\
\text { error of } \\
\exp R \\
10 \% \mathrm{~mm} .\end{array}$ \\
\hline days & days & & & & & \\
\hline 2 & 108 & 4.41 & 2.70 & 1.71 & 1.66 & .126 \\
\hline 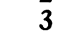 & 107 & 4.26 & 2.64 & 1.62 & 1.64 & .123 \\
\hline 4 & 106 & 4.07 & 2.56 & 1.51 & 1.61 & .130 \\
\hline 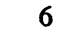 & 104 & 386 & 2.45 & 1.41 & 1.57 & .123 \\
\hline 7 & 103 & 30 & 2.45 & 1.49 & 1.58 & .124 \\
\hline 0 & 102 & 4.02 & 2.44 & 1.58 & 1.59 & .125 \\
\hline 21 & (n) & 20 & 1.0 & 1.1 & 1.4 & .123 \\
\hline 38 & & 2.6 & 1.71 & 0.90 & 1.5 & .156 \\
\hline
\end{tabular}

Reference day $=$ day of transfusion; $N=110 \pm 10$ ref $\mathrm{D}=2.70 \pm .020$; ref $\mathrm{R}=1.71 \pm .100 ; 2 \times \mathrm{SE}$ obs $\mathrm{T}$ $=.120 ; 2 \times \mathrm{SE}$ obs $\mathrm{D}=.020 ; 2 \times \mathrm{SE}$ obs $\mathrm{R}=.100$. parison of $\exp R$ with obs $R$ shows an initial significant gain of recipient's cells from the second to the seventh day of transfusion, similar to that seen in the two studies on the normal recipient. From the tenth to the 28th day there was a steady gain in recipient's cells. The obs $R$ (observed recipient's cell count) on the 28th day was $2.082 \pm$ .100 millions per mm..$^{3}$ whereas the $\exp R$ (expected recipient's cell count) was $0.548 \pm 0.090$

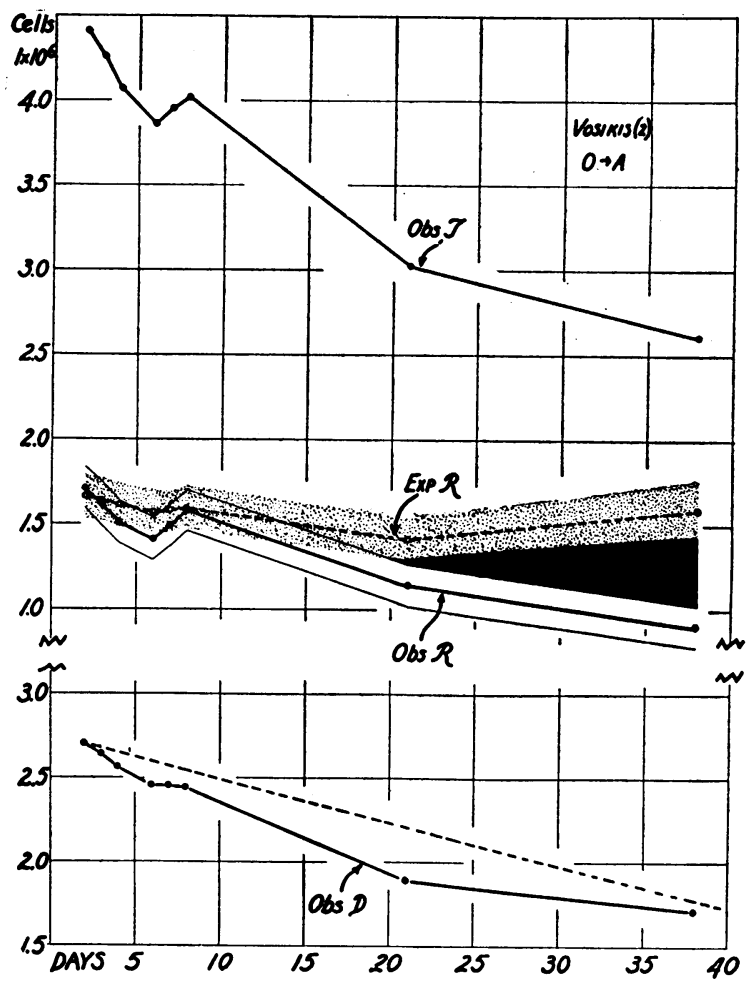

Fig. 6. Data from an Infant with Cooley's Anemia Belonging to Group A Who Received a TransFusion of Group O Blood from a Donor with CoOley's TraIT

The upper graph contains the plotted values for obs $T$, obs $R$, and $\exp R$. The lower graph contains values for obs $D$ plotted on the same scale. The broken line intersects the $\mathrm{X}$ axis at 110 days. The clear zone around the values for obs $R$ and the stippled zone around the values for $\exp R$ indicate twice the standard error on either side of the value. The black area marks a significant deficit in the recipient's cells which by the 38th day after transfusion had attained a magnitude of $43 \%( \pm 11 \%)$. Note the lack of the initial increase in recipient's cells after transfusion observed in the preceding cases. From the 21 st to the 38 th day the total cell count fell to a greater extent than the inagglutinable cell count. This suggests an effect from the deficit of recipient's cells in raising the observed inagglutinable cell count. 
million. This represents a gain in the recipient's cells of approximately $279 \%( \pm 23 \%)$. Although this is calculated on cell counts per unit volume it also is an indication of the total increase in recipient's cells in the body because both the expected counts and the observed counts are based on unit volumes and therefore represent a proportion which should be uniform throughout the body. A large dip in the curve of the inagglutinable cell counts (obs $D$ ) coincided with the period during which there was a great total increase in the number of observed recipient's cells. This is similar to the phenomenon observed in the two preceding studies on a normal subject.

In contrast to the preceding study, the data in Table IX and Figure 6 show measurements of a deficit of recipient's cells. The patient was an infant belonging to group A who had Cooley's anemia (40). He was given cells from a donor with Cooley's trait. The tagged cells were estimated to disappear from the circulation in 110 days. The initial recipient's cell count was about 1.50 millions per mm. ${ }^{3}$. From the 20th to the 38th day a significant discrepancy was noted between the expected recipient's cell count $(\exp R)$ and the observed recipient's cell count (obs $R$ ), but this time the $\exp R$ exceeded the $o b s R$. On the 38th day the $\exp R$ was $1.59 \pm .156$ millions per $\mathrm{mm}^{3}$ whereas the obs $R$ was $0.900 \pm .100$ million. This represents a deficit of recipient's cells of $43 \%$ $( \pm 11 \%)$. It should be noted that the term deficit is employed rather than the more expected word loss because this method does not distinguish between a diminution of recipient's cells due to increased loss and a deficit resulting from a diminished rate of hemopoiesis.

\section{CALCULATION OF THE RECIPIENT'S ERYTHRO- CYTE COUNT WHEN COMPLICATED BY SUB- SEQUENT TRANSFUSIONS OF CELLS OF HOMOLOGOUS BLOOD GROUP}

Occasionally during the study of a patient with anemia by following the disappearance of transfused inagglutinable cells the blood deficit becomes so great as to necessitate further blood transfusions. If blood of the group of the recipient is given, the study can be continued provided the method of computation is revised and the blood of homologous group is assumed to disap- pear at a normal rate. The accuracy is somewhat less than with the method previously presented.

The calculation is based on an expansion of the concept depicted in Figure 2. Under the altered conditions of the study, the erythrocytes of homologous blood group which have been transfused from the second donor are indistinguishable from those of the recipient by the serologic method used in counting, so that the total cell count minus the inagglutinable cell count gives a value which is the sum of the recipient's own cells plus those of the second donor. As in the first concept in Figure 2, the recipient's own cells should remain constant in number but the second component of the agglutinable cells, those of the second donor, should diminish in a systematic fashion similar to the inagglutinable cells of the first donor. This results in a graphic presentation in which Figure 2 is modified by the addition of a second right triangle as in Figure 7. At the time of the second transfusion (with homologous group blood) the count of agglutinable cells is augmented by the value $R^{\prime}$ which is plotted as the leg of the new right triangle. The base of the new triangle is adjacent to the side of the rectangle for ref $R$ but is by assumption extended for 120 days, the time of survival of cells of the second transfusion. The total number of days representing the base of this triangle is denoted as $\mathrm{N}^{\prime}$ and any time under consideration which occurs in $\mathrm{N}^{\prime}$ is designated as $\mathrm{n}^{\prime}$. When $\mathrm{n}$ in the first triangle occurs at a time after the second transfusion it will coincide on the graph with $n^{\prime}$ in the second triangle but $\mathrm{n}$ will be the number of days from ref $D$ whereas $n^{\prime}$ will be the number of days from ref $R^{\prime}$.

As in Figure 2, the values in Figure 7 assume that no changes in cell counts have occurred due to plasma shifts and the total number of the recipient's own cells in the body remains the same throughout the study. The increase in obs $R$ (observed recipient's cell count by the method of counting employed) is due to the cells of the second transfusion. Therefore we have the expression

$$
\text { obs } R^{\prime}=\text { obs } R_{2}-\text { obs } R_{1} \text {, }
$$

where obs $R_{1}$ is the observed recipient's cell count just before the second transfusion and $o b s R_{2}$ is the observed recipient's cell count soon after the second transfusion. To determine a point of reference comparable to ref $R$ insofar as plasma volume is concerned the observed value for $R^{\prime}$ may be corrected by the proportionality $\frac{D n}{\text { obs } D}$ thus:

$$
\begin{gathered}
\frac{\text { ref } R^{\prime}}{\text { obs } R_{2}-\text { obs } R_{1}}=\frac{D n}{\text { obs } D} ; \\
\text { ref } R^{\prime}=\left(\text { obs } R_{2}-\text { obs } R_{1}\right) \times \frac{D n}{\text { obs } D} .
\end{gathered}
$$

Plasma shifts will dilute or concentrate the cells from the second transfusion in the same proportion and in the same direction as they do those of the first transfusion which are biologically tagged. Therefore

$$
\frac{\mathrm{Dn}}{\mathrm{obs} \mathrm{D}}=\frac{\mathrm{R}^{\prime} \mathbf{n}^{\prime}}{\mathrm{obs} \mathrm{R}^{\prime}}
$$




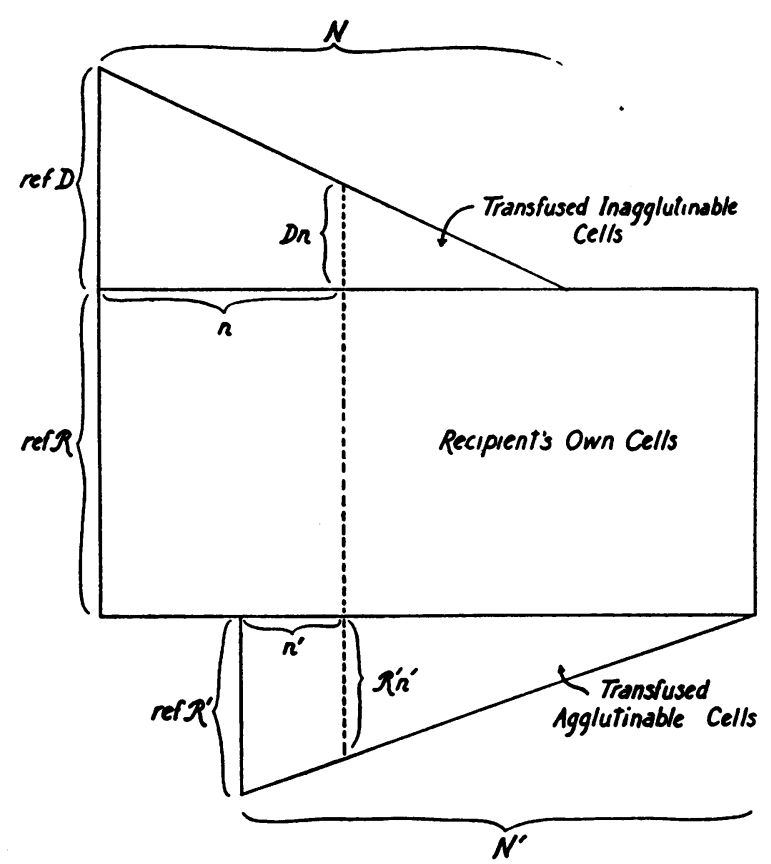

Fig. 7. Constructed Figure Which Is an ExtenSion of the Concept in Figure 2. It Represents Data from a Hypothetical Transfusion Experiment Plotted on Cartesian Coordinates, Assuming That There Are No Plasma Shifts and That the Total Number of Recipient's Cells in the Body Remains Constant DURING the Experiment

The study is complicated by a transfusion of cells of the same group as the recipient some time after the initial transfusion of biologically tagged red cells. The added lower right triangle is a graph of the transfused cells of the same group as those of the recipient, and hence agglutinable. The life span of the cells of the second transfusion is designated by the time $N^{\prime}$ in days. The count of the cells of the supplementary transfusion is designated as ref $R^{\prime}$ taken at a second reference time. Any time under consideration is designated as $\mathrm{n}^{\prime}$ days after ref $R^{\prime}$ and coincides with an $\mathrm{n}$ in the upper triangle which is measured in days from ref $D . \mathrm{R}^{\prime} \mathrm{n}^{\prime}$ diminishes daily during the study. Ref $R+R^{\prime} n^{\prime}$ represents the theoretical count of the agglutinable cells, if there is no change in recipient's cells during the study and if corrections are made for plasma shifts.

The cells of the second transfusion are assumed to leave the body in a rectilinear curve so that the concentration of $R^{\prime}$ at any time $n^{\prime}$, if the plasma volume remained the same as that of the reference time, would be:

(14) $\frac{R^{\prime} n^{\prime}}{\text { ref } R^{\prime}}=\frac{N^{\prime}-n^{\prime}}{N^{\prime}} ; \quad R^{\prime} n^{\prime}=\operatorname{ref} R^{\prime} \times \frac{N^{\prime}-n^{\prime}}{N^{\prime}}$.

In (13) substituting for $\mathrm{Dn}$ from (1) and for $\mathrm{R}^{\prime} \mathrm{n}^{\prime}$ from (14) we have

$$
\begin{aligned}
& \frac{\text { ref } D \times \frac{N-n}{N}}{\text { obs } D}=\frac{\text { ref } R^{\prime} \times \frac{N^{\prime}-n^{\prime}}{N^{\prime}}}{\text { obs } R^{\prime}} ; \\
& \text { obs } \mathrm{R}^{\prime} \times \frac{\mathrm{N}-\mathrm{n}}{\mathrm{N}} \times \text { ref } \mathrm{D} \\
& =\text { obs } D \times \frac{N^{\prime}-n^{\prime}}{N^{\prime}} \times \text { ref } R^{\prime} \text {; } \\
& \text { obs } R^{\prime}=\text { obs } D \times \frac{N^{\prime}-n^{\prime}}{N-n} \times \frac{\text { ref } R^{\prime}}{\text { ref } D} \times \frac{N}{N^{\prime}} .
\end{aligned}
$$

The expression in (15) will be an equality provided that (a) the biologically tagged red cells disappear from the circulation in a rectilinear curve, $(b)$ the observed inagglutinable cell counts deviate from the straight line slope only by shif ts in plasma and not by increases in total number of red cells (discussed further on), and (c) that the cells of the second transfusion disappear in approximately 120 days after transfusion, as assumed, since there is no direct method of measurement.

To correspond with our previous nomenclature we will change the term obs $R^{\prime}$ in (15) to $\exp R^{\prime}$ and have

$$
\exp R^{\prime}=\text { obs } D \times \frac{N^{\prime}-n^{\prime}}{N-n} \times \frac{\operatorname{ref} R^{\prime}}{\operatorname{ref} D} \times \frac{N}{N^{\prime}} .
$$

Then the sum of the expected recipient's own erythrocyte count and that of the expected count for cells from the second transfusion (exp $R+$ $\exp R^{\prime}$ ) should equal the observed recipient's cell count (obs $R$ ), provided that the assumptions mentioned are correct and that there has been no gain or deficit in the recipient's own cells. If there is a discrepancy between expected and observed values, this difference may be employed as a measure of gain or deficit of recipient's cells.

\section{Computation of the standard error of $\exp R+$ $\exp R^{\prime}$}

The expression in (16) can be rearranged as follows:

$$
\exp R^{\prime}=\text { obs } D \times \frac{\text { ref } R^{\prime}}{\operatorname{ref} D} \times \frac{N}{N-n} \times \frac{N^{\prime}-n^{\prime}}{N^{\prime}} .
$$

Applying the general equations (5) and (6) we have

(17) $S E \exp R^{\prime}=\exp R^{\prime}\left\{\left(\frac{S E \text { obs } D}{\text { obs } D}\right)^{2}\right.$

$$
\begin{aligned}
& +\left(\frac{\text { SE ref } R^{\prime}}{\operatorname{ref} R^{\prime}}\right)^{2}+\left(\frac{S E \text { ref } D}{\text { ref } D}\right)^{2} \\
& \times\left[\frac{(N \pm S E N)(N-n)}{(N \pm S E N-n) N}-1\right]^{2} \\
& \left.\quad+\left[\frac{\left(N^{\prime} \pm S E N^{\prime}-n^{\prime}\right) N^{\prime}}{\left(N^{\prime} \pm S E N^{\prime}\right)\left(N^{\prime}-n^{\prime}\right)}-1\right]^{2}\right\}^{\prime}
\end{aligned}
$$


The penultimate factor is derived as in (8) and (9). The last factor is obtained as follows:

$$
\begin{aligned}
& \operatorname{SE} \frac{N^{\prime}-n^{\prime}}{N^{\prime}}=\frac{N^{\prime} \pm S E N^{\prime}-n^{\prime}}{N^{\prime} \pm S E N^{\prime}}-\frac{N^{\prime}-n^{\prime}}{N^{\prime}} \\
&= {\left[\frac{\left(N^{\prime} \pm S E N^{\prime}-n^{\prime}\right) N^{\prime}}{\left(N^{\prime} \pm S E N^{\prime}\right)\left(N^{\prime}-n^{\prime}\right)}-1\right] } \\
& \times\left(\frac{N^{\prime}-n^{\prime}}{N^{\prime}}\right), \\
& \frac{\operatorname{SE}\left(\frac{N^{\prime}-n^{\prime}}{N^{\prime}}\right)}{\frac{N^{\prime}-n^{\prime}}{N^{\prime}}}=\frac{\left(N^{\prime} \pm N^{\prime}-n^{\prime}\right) N^{\prime}}{\left(N^{\prime} \pm N^{\prime}\right)\left(N^{\prime}-n^{\prime}\right)}-1 .
\end{aligned}
$$

The standard error of the sum of $\exp R$ and $\exp R^{\prime}$ is obtained:

(18) $\mathrm{SE}\left(\exp \mathrm{R}+\exp \mathrm{R}^{\prime}\right)$

$$
=\sqrt{(\mathrm{SE} \exp \mathrm{R})^{2}+\left(\mathrm{SE} \exp \mathrm{R}^{\prime}\right)^{2}} \text {. }
$$

\section{Experimental application of the method}

In all applications, deviations exceeding twice the standard error on either side of the computed value are considered significant. The data in Table $\mathrm{X}$ and Figure 8 illustrate the application of equations (12), (16), (17), and (18) to the study of the net gain or deficit of the patient's erythrocytes in the infant with Cooley's anemia. At the beginning of the study the recipient belonging to group A was transfused with red cells from a subject with Cooley's trait who belonged to group $\mathrm{O}$. The transfused erythrocytes disappeared from the circulation in 100 days in a rectilinear curve. During the first 32 days the total cell count (obs $T$ ) dropped from approximately 4.0 millions per $\mathrm{mm}^{3}$ to 2.17 millions. The expected recipient's cell count at the end of that period was computed to be $2.37 \pm .133$ millions. Compared with the observed recipient's cell count at that time, it was apparent that a deficit of $38 \%( \pm 7 \%)$ had developed. On the 33rd day, because of the precarious state of the patient, a transfusion of blood from a normal donor was given. This time the transfused blood belonged to group $\mathrm{A}$, the same as that of the recipient. The cell counts on that day, some hours after transfusion, were taken as the reference

\begin{tabular}{|c|c|c|c|c|c|c|c|c|c|c|c|}
\hline $\begin{array}{c}\text { Time } \\
\text { in } \\
\text { days }\end{array}$ & $\mathbf{N}-\mathbf{n}$ & $\mathbf{N}^{\prime}-\mathbf{n}^{\prime}$ & obs $\mathrm{T}$ & obs D & obs $\mathbf{R}$ & $\exp R$ & $\underset{\operatorname{exp~R}}{2 \mathrm{SE}}$ & $\exp \mathrm{R}^{\prime}$ & $\underset{\exp R^{\prime}}{2 \mathrm{SE}}$ & $\underset{\exp R^{\prime}}{\exp R}$ & $\underset{\exp \mathbf{R}^{2} \mathbf{S E}}{+}$ \\
\hline $\begin{array}{r}2 \\
4 \\
5 \\
6 \\
7 \\
8 \\
9 \\
32 \\
33 \\
34 \\
35 \\
36 \\
37 \\
39 \\
65 \\
67 \\
68 \\
69 \\
81 \\
96 \\
98 \\
100 \\
102 \\
103 \\
104\end{array}$ & $\begin{array}{r}99 \\
97 \\
96 \\
95 \\
94 \\
93 \\
92 \\
69 \\
68 \\
67 \\
66 \\
65 \\
64 \\
62 \\
36 \\
34 \\
33 \\
32 \\
20 \\
5 \\
1 \\
0\end{array}$ & $\begin{array}{r}119 \\
118 \\
117 \\
116 \\
114 \\
88 \\
86 \\
85 \\
84 \\
72 \\
57 \\
55\end{array}$ & $\begin{array}{l}3.78 \\
3.53 \\
3.49 \\
3.91 \\
4.06 \\
3.72 \\
3.88 \\
2.17 \\
6.01 \\
5.59 \\
5.85 \\
5.10 \\
5.18 \\
5.63 \\
3.89 \\
3.85 \\
3.86 \\
3.85 \\
3.20 \\
2.52 \\
2.24 \\
1.82 \\
2.14 \\
2.37 \\
2.23\end{array}$ & $\begin{array}{c}1.13 \\
1.06 \\
1.06 \\
1.20 \\
1.20 \\
1.18 \\
1.19 \\
0.70 \\
0.59 \\
0.53 \\
0.61 \\
0.57 \\
0.58 \\
0.61 \\
0.32 \\
0.32 \\
0.30 \\
0.28 \\
0.14 \\
.033 \\
0.01 \\
.013 \\
.011 \\
.016\end{array}$ & $\begin{array}{l}2.65 \\
2.46 \\
2.42 \\
2.70 \\
2.85 \\
2.53 \\
2.68 \\
1.46 \\
5.41 \\
5.06 \\
5.23 \\
4.52 \\
4.59 \\
5.01 \\
3.56 \\
3.53 \\
3.55 \\
3.56 \\
3.05 \\
2.48 \\
2.22 \\
1.80 \\
2.12 \\
2.35\end{array}$ & $\begin{array}{l}2.54 \\
2.54 \\
2.93 \\
2.98 \\
2.96 \\
3.01 \\
2.37 \\
2.05 \\
1.83 \\
2.18 \\
2.06 \\
2.13 \\
2.31 \\
2.12 \\
2.18 \\
2.14 \\
2.04 \\
1.71 \\
1.55\end{array}$ & $\begin{array}{l}.101 \\
.124 \\
.116 \\
.118 \\
.118 \\
.121 \\
.133 \\
.120 \\
.110 \\
.132 \\
.128 \\
.136 \\
.155 \\
.306 \\
.361\end{array}$ & $\begin{array}{l}3.54 \\
4.15 \\
3.92 \\
4.00 \\
4.25 \\
3.01 \\
3.04\end{array}$ & $\begin{array}{l}.258 \\
.306 \\
.294 \\
.305 \\
.415 \\
.434 \\
.503\end{array}$ & $\begin{array}{l}5.38 \\
6.33 \\
5.98 \\
6.13 \\
6.56 \\
5.13 \\
5.22\end{array}$ & $\begin{array}{l}.280 \\
.333 \\
.319 \\
.333 \\
.442 \\
.530 \\
.618\end{array}$ \\
\hline
\end{tabular}
values. The obs $T$ (observed total cell count)

TABLE $X$

Data of experiment in Figure 8 on transfusion of Cooley's trait group $O$ cells to Cooley's anemia group $A$ and transfusion of normal group $A$ cells to same recipient 33 days later

Reference day $=$ two days after first transfusion; second reference day $=33$ days after first transfusion (immediately after second transfusion); $N=99 \pm 10 ; N^{\prime}=$ assumed $120 \pm 10 ;$ ref $D=1.13 \pm 0.020 ;$ ref $R=2.65 \pm 0.100$; ref $\mathrm{R}^{\prime}=5.164 \pm .281 ; 2 \times \mathrm{SE}$ obs $\mathrm{T}=.120 ; 2 \times \mathrm{SE}$ obs $\mathrm{D}=.010 ; 2 \times \mathrm{SE}$ obs $\mathrm{R}=.100$. 


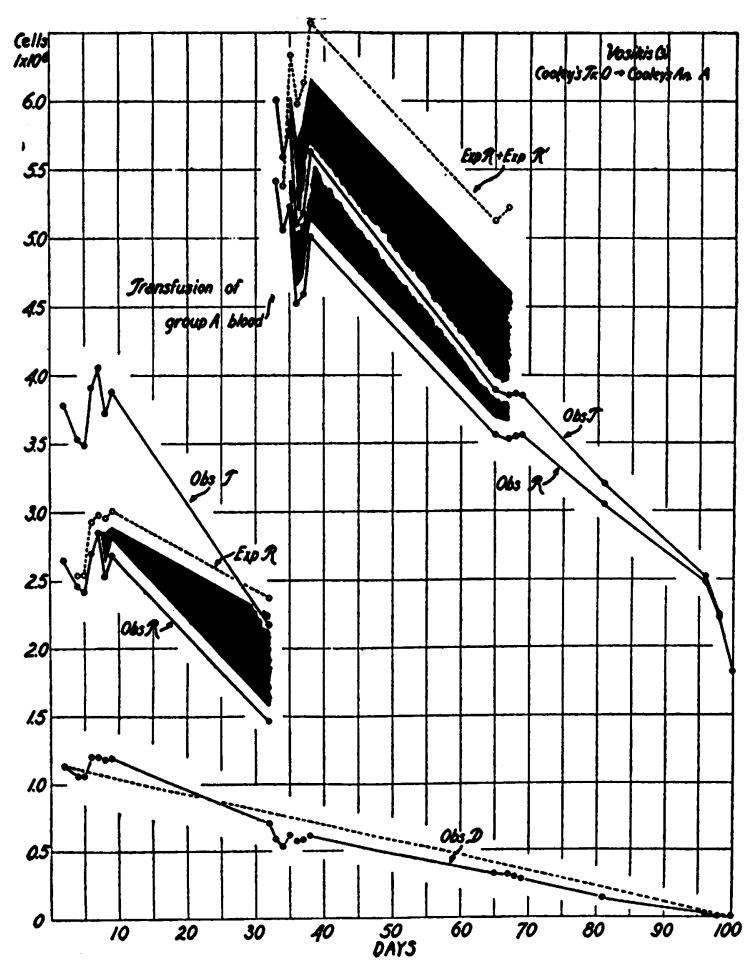

Fig. 8. Data from an Infant with Cooley's Anemia Belonging to Group A Who Received a Transfusion of Group O Blood from a Donor with Cooley's TraIT

The study was complicated by a supplementary transfusion of group A blood from a normal donor 33 days after the initial transfusion.

The data are plotted on a single scale. The broken line near the values for obs $D$ intersects the $\mathrm{X}$ axis at 100 days. During the first 32 days the patient developed a significant deficit of his own cells, as demonstrated by the black area enclosed by the values for exp $R$ and $o b s$ $R$, exp $R$ being much the greater. After the supplementary transfusion the values for obs $R$ are to be compared with those for $\exp R+\exp R^{\prime}$. This shows that the deficit of recipient's cells persisted during that part of the study in which the error of computation for exp $R$ $+\exp R^{\prime}$ was within reasonable limits. Note the absence of the normal post-transfusion increase in recipient's cells.

was 6.1 millions, as compared with 2.17 millions on the previous day. The value 5.164 millions was computed for ref $R^{\prime}$ from equation (12). During the next 34 days the computed value $\exp R+\exp R^{\prime}$ was much higher than the observed recipient's cell count ( obs $R$ ). On the 67 th day of the study the deficit of recipient's cells was computed as $32 \%( \pm 11 \%)$.

\section{CONCENTRATION OF INAGGLUTINABLE CELLS CHANGED BY PLASMA SHIFTS AND BY GAIN OR LOSS OF RECIPIENT'S CELLS}

Inspection of Figures $3-6$ and 8 shows that fluctuations in the total cell counts (obs $T$ ) are usually accompanied by similar variations in the counts of the inagglutinable cells (obs $D$ ). Since these values are obtained by independent measurements, it was concluded earlier in the paper that the changes in concentration of the cells must be caused by plasma shifts and the equations which have been presented recognize this. After the values for $\exp R$ were computed and charted another phenomenon became evident for the first time. In each case in which there was a significant gain in the total number of the recipient's own cells in the body there were dips in the curve made by the plotted values for obs $D$. Rises in the curve have not been so evident when the computation of $\exp R$ shows a deficit of recipient's cells.

A consideration of the procedure by which counts of blood cells are made demonstrates that the observed inagglutinable cell count can be increased over the expected mean either by shrinkage of the plasma volume of the recipient or by a deficit in the total number of recipient's cells in the body. Likewise, a decrease in the concentration of the inagglutinable cells per unit volume can be caused either by an increase in plasma volume or by augmentation of the total number of recipient's cells in the body.

Counts of erythrocytes are made from samples of blood which are measured by drawing a column of whole blood into a pipette up to a mark. Let us imagine for simplicity that the column of the pipette, from tip to mark, is calibrated in 100 equal divisions and that the bore is uniform throughout. Furthermore, let us suppose that the total blood volume of the subject is $5,000 \mathrm{ml}$., the hematocrit is 50 , and that exactly $10 \%$ of the erythrocytes are inagglutinable cells which have been transfused in the course of study. When an aliquot of this blood mixture is sampled in the hypothetical pipette by drawing whole blood up to the mark, the pipette should contain 50 units of plasma, 45 units of recipient's cells, and 5 units of inagglutinable cells. Since we arbitrarily assumed our pipette to have 100 units, the values given are the percentage of the whole blood volume contributed by 
TABLE XI

Examples of changes in concentrations of inagglutinable cells with variations in volume of plasma and recipient's cells

\begin{tabular}{|c|c|c|c|c|c|c|c|c|}
\hline \multirow{2}{*}{$\begin{array}{l}\text { Examples } \\
\text { (Total number of donor's cells in body is } \\
\text { constant in all examples) }\end{array}$} & \multicolumn{4}{|c|}{ Volumes in entire circulation } & \multicolumn{4}{|c|}{$\begin{array}{l}\text { Distribution in blood sample in pipette } \\
\text { calibrated in } 100 \text { units }\end{array}$} \\
\hline & $\begin{array}{l}\text { Whole } \\
\text { blood } \\
\text { volume }\end{array}$ & $\begin{array}{l}\text { Plasma } \\
\text { volume }\end{array}$ & $\begin{array}{c}\text { Recipient's } \\
\text { cell } \\
\text { volume }\end{array}$ & $\begin{array}{l}\text { Donor's } \\
\text { cell } \\
\text { volume }\end{array}$ & Plasma & $\begin{array}{c}\text { Recipient's } \\
\text { cells }\end{array}$ & $\begin{array}{l}\text { Donor's } \\
\text { cells }\end{array}$ & $\begin{array}{l}\text { Ratio } \\
\text { R/D* }\end{array}$ \\
\hline $\begin{array}{l}\text { 1. Reference example } \\
\text { 2. Plasma increased } \\
\text { 3. Plasma decreased } \\
\text { 4. Recipient's cells increased } \\
\text { 5. Recipient's cells decreased }\end{array}$ & $\begin{array}{l}m l \\
5000 \\
6000 \\
4000 \\
6000 \\
4000\end{array}$ & $\begin{array}{c}m l \\
2500 \\
3500 \\
1500 \\
2500 \\
2500\end{array}$ & $\begin{array}{c}m l . \\
2250 \\
2250 \\
2250 \\
3250 \\
1250\end{array}$ & $\begin{array}{l}m l . \\
250 \\
250 \\
250 \\
250 \\
250\end{array}$ & $\begin{array}{l}\text { units } \\
50.0 \\
58.3 \\
37.5 \\
41.6 \\
62.5\end{array}$ & $\begin{array}{l}\text { units } \\
45.0 \\
37.5 \\
56.2 \\
54.1 \\
31.2\end{array}$ & $\begin{array}{l}\text { units } \\
5.0 \\
4.1 \\
6.2 \\
4.1 \\
6.2\end{array}$ & $\begin{aligned} 9: 1 \\
9: 1 \\
9: 1 \\
13: 1 \\
5: 1\end{aligned}$ \\
\hline
\end{tabular}

* Ratio of recipient's cell count to donor's cell count.

each of the components. The values used are placed in Table XI as the "reference example."

In example 2 in Table XI it is assumed that the plasma volume has been expanded by $1,000 \mathrm{ml}$., as compared with the reference example, but the total number of recipient's and donor's cells in the body is unaltered. This change, of course, results in dilution of the inagglutinable cells and the count per unit volume is diminished. When the plasma volume shrinks by $1,000 \mathrm{ml}$. instead (example 3 ) the cell counts are augmented in excess of the reference example. In all three cases, however, the proportion of recipient's to donor's cells remains the same so that this relationship can be accurately determined by comparing total cell counts and counts of inagglutinable cells of specimens collected in pipettes.

In examples 4 and 5 it is assumed that the plasma volume is the same as that in the reference example and the total number of tagged inagglutinable cells is unaltered, but in one case there is a great increase in total recipient's cells and in the other a great deficit. It should be noted that the increase in the amount of inagglutinable cells in the pipette is the same whether the total blood volume has been decreased by $1,000 \mathrm{ml}$. of plasma or a similar volume of recipient's red cells. An increase in the total blood volume by either 1,000 ml. of plasma or a similar amount of recipient's red cells will cause the same diminution in the inagglutinable cell count, as compared with the reference example. It is important to recognize the concept that the tagged red cells are completely mixed with both plasma and recipient's cells and are therefore diluted by the addition of recipient's cells as well as by the plasma, and the counts per unit volume are increased by the loss of recipient's cells as well as by shrinkage of plasma volume.

The equation (4) for the computation of $\exp R$ contains obs $D$ as its only observed value at time n. The magnitude of $\exp R$ depends on fluctuations of $o b s D$ during the time of study. It follows that when obs $D$ is small, $\exp R$ will be correspondingly small. This is true whether there is expansion of the plasma volume or an increase in the total number of recipient's cells. $\operatorname{Exp} R$ therefore fluctuates with the total blood volume and does not distinguish which of the components of the blood volume has been altered. But if the value for $\exp R$ differs from obs $R$, the proportion between the recipient's cells and the donor's cells differs from that calculated from the time $n$ and the discrepancy is then a measure of the gain or deficit of recipient's cells.

\section{SUMMARY}

Refinements in the procedure for the counting of inagglutinable cells after transfusion to a recipient have been described and their error of estimate computed.

A method is described for the measurement of the net gain or deficit of the recipient's cells during a prolonged period of study. This depends on the transfusion to the subject of erythrocytes of heterologous group. The rate of loss from the body of the transfused cells is determined by repeated counts of the inagglutinable cells by a modification of the Ashby technique. When the rate of disappearance of the transfused cells is found to be rectilinear the inagglutinable erythrocytes can 
be employed as biologically tagged cells. Any departure from the expected proportion of recipient's to donor's cells can be measured by making counts of total cells and inagglutinable cells. Equations have been developed for computing the expected recipient's cell count at any time during the study. A significant discrepancy between the expected count and the observed count can be used as a measure of the net gain or deficit of the recipient's cells. Examples of the clinical application of this method are presented.

Proof is presented for the fact that the total cell counts and the inagglutinable cell counts are modified by changes in plasma volume. The inagglutinable cell counts are also modified by net gains or deficits of the recipient's red cells.

\section{ACKNOWLEDGMENT}

The authors wish to express appreciation to Professor Clinton D. Janney of the Department of Physiology of the State University of Iowa for his kind and expert assistance in the mathematical problems of this study.

\section{BIBLIOGRAPHY}

1. Ashby, W., The determination of length of life of transfused blood corpuscles in man. J. Exper. Med., 1919, 29, 267.

2. Landsteiner, K., Levine, P., and Janes, M. L., On the development of isoagglutinins following transfusions. Proc. Soc. Exper. Biol. \& Med., 1928, 25,672 .

3. Isaacs, R., Properties of young erythrocytes in relation to agglutination and their behavior in hemorrhage and transfusion. Arch. Int. Med., 1924, 33, 193.

4. Callender, S. T., Powell, E. O., and Witts, L. J., The life-span of the red cell in man. J. Path. \& Bact., 1945, 57, 129.

5. Young, L. E., Platzer, R. F., and Rafferty, J. A., Differential agglutination of human erythrocytes; evaluation of technique. J. Lab. \& Clin. Med., 1947, 32, 489.

6. McKerns, K .W., and Denstedt, O. F., Agglutination of erythrocytes containing sulphaemoglobin-further evidence of specific agglutination. Canadian J. Research, 1949, E 27, 164.

7. Dekkers, $H$. J. N., The fate of the transfused red blood cells. Acta med. Scandinav., 1939, 99, 587.

8. Loutit, J. F., Discussion on the life and death of the red blood corpuscle. Proc. Roy. Soc. Med., 1946, 39, 757.

9. Ashiby, W., The span of life of the red blood cell. A résumé. Blood, 1948, 3, 486.
10. Callender, S. T., Powell, E. O., and Witts, L. J., Normal red-cell survival in men and women. $J$. Path. \& Bact., 1947, 59, 519.

11. Mollison, P. L., and Young, I. M., Survival of the transfused erythrocytes of stored blood. Lancet, $1940,2,420$.

12. Mollison, P. L., and Young, I. M., In vivo survival in the human subject of transfused erythrocytes after storage in various preservative solutions. Quart. J. Exper. Physiol., 1942, 31, 359.

12a. Mollison, P. L., Personal communication.

13. Loutit, J. F., Mollison, P. L., and Young, I. M., Citric acid-sodium citrate-glucose mixtures for blood storage. Quart. J. Exper. Physiol., 1943, 32, 183.

14. Bushby, S. R. M., Kekwick, A., Marriott, H. L., and Whitby, L. E. H., Survival of stored red cells after transfusion. Lancet, 1940, 2, 414.

15. Denstedt, O. F., Osborne, D. E., Stanfield, H., and Rochlin, I., The survival of preserved erythrocytes after transfusion. Canad. M.A.J., 1943, 48, 477.

16. Thalhimer, W., and Taylor, E. S., The transfusion of centrifuged human type $O$ cells resuspended and stored in 10 per cent corn syrup. J.A.M.A., 1945, 127, 1096.

17. Ashby, W., Transfused blood; blood destruction in pernicious anemia. J. Exper. Med., 1921, 34, 147.

18. Wearn, J. T., Warren, S., and Ames, O., The length of life of transfused erythrocytes in patients with primary and secondary anemia. Arch. Int. Med., 1922, 29, 527.

19. Singer, K., King, J. C., and Robin, S., The life span of the megalocyte and the hemolytic syndrome of pernicious anemia. J. Lab. \& Clin. Med., 1948, 33, 1068.

20. Singer, K., Robin, S., King, J. C., and Jefferson, R. N., The life span of the sickle cell and the pathogenesis of sickle cell anemia. J. Lab. \& Clin. Med., 1948, 33, 975.

21. Callender, S. T. E., Nickel, J. F., and Moore, C. V., Sickle cell disease; studied by measuring the survival of transfused red blood cells. J. Lab. \& Clin. Med., 1949, 34, 90.

22. Dacie, J. V., and Mollison, P. L., Survival of normal erythrocytes after transfusion to patients with familial haemolytic anaemia (acholuric jaundice). Lancet, 1943, 1, 550.

23. Loutit, J. F., and Mollison, P. L., Haemolytic icterus (acholuric jaundice), congenital and acquired. $\mathrm{J}$. Path. \& Bact., 1946, 58, 711.

24. Mollison, P. L., The survival of transfused erythrocytes, with special reference to cases of acquired haemolytic anaemia. Clin. Sc., 1947, 6, 137.

25. Dacie, J. V., Transfusion of saline-washed red cells in nocturnal haemoglobinuria (MarchiafavaMicheli Disease). Clin. Sc., 1948, 7, 65.

26. Mollison, P. L., The survival of transfused erythrocytes in haemolytic disease of the newborn. Arch. Dis. Childhood, 1943, 18, 161. 
27. Mollison, P. L., and Cutbush, M., Exchange transfusion in haemolytic disease of the newborn. Lancet, 1948, 2, 522.

28. Young, L. E., and Lawrence, J. S., Atypical hemolytic anemia; observations with particular reference to the use of transfusions in the study of hemolytic mechanisms. Arch. Int. Med., 1946, 77, 151.

29. Ebert, R. V., and Emerson, C. P., Jr., A clinical study of transfusion reactions; the hemolytic effect of group-O blood and pooled plasma containing incompatible isoagglutinins. J. Clin. Invest., 1946, 25, 627.

30. Young, L. E., and Kariher, D. H., Hemolytic transfusion reactions due to $\mathrm{Rh}$ incompatibility; manifestation of sensitivity to $\mathrm{Rh}$ factor many years after immunization by pregnancy. J.A.M.A., 1945, 127, 627.

31. Witebsky, E., Klendshoj, N. C., and McNeil, C., Potent typing sera produced by treatment of donors with isolated blood group specific substances. Proc. Soc. Exper. Biol. \& Med., 1944, $55,167$.

32. Osborne, D. E., and Denstedt, O. F., Estimation of cell survival after transfusion by selective agglutination. J. Clin. Invest., 1947, 26, 655.
33. Cooksey, W. B., and Puschelberg, G. C., Disposable, fine mesh filter for blood and plasma. J.A.M.A., 1948, 137, 788.

34. Malloy, H. T., and Evelyn, K. A., The determination of bilirubin with the photoelectric colorimeter. J. Biol. Chem., 1937, 119, 481.

35. Flink, E. B., and Watson, C. J., A method for quantitative determination of hemoglobin and related heme pigments in feces, urine, and blood plasma. J. Biol. Chem., 1942, 146, 171.

36. DeGowin, E. L., Hardin, R. C., and Alsever, J. B., Blood Transfusion. W. B. Saunders Co., Philadelphia, 1949.

37. Berkson, J., Magath, T. B., and Hurn, M., The error of estimate of the blood cell count as made with the hemocytometer. Am. J. Physiol., 1940, 128, 309.

38. Ponder, E., Hemolysis and Related Phenomena. Grune \& Stratton, New York, 1948, p. 356.

39. Barnes, D. W. H., and Loutit, J. F., "Avidity" of anti-A agglutinating sera. Quart. J. Exper. Physiol., 1947, 34, 69.

40. Hamilton, H. E., Sheets, R. F., and DeGowin, E. L., Studies with inagglutinable erythrocyte counts. II. Analysis of mechanism of Cooley's anemia. J. Clin. Invest., 1950, 29, 714. 